\title{
Optimisation of Medium Formulation and Growth Conditions for Xylanase Production by Aspergillus brasiliensis in Submerged Fermentation (SmF)
}

Hooi Ling Ho ${ }^{*}$ and Jamila Said Hood

Faculty of Applied Sciences, UCSI University, 1, Jalan Menara Gading, UCSI Heights, Cheras, 56000 Kuala Lumpur, Malaysia.

"Corresponding author: Hooi Ling Ho, Faculty of Applied Sciences, UCSI University, 1, Jalan Menara Gading, UCSI Heights, Cheras, 56000 Kuala Lumpur, Malaysia, Tel:+6012 369 9854; Fax : +603 9102 2614; E-mail: hohl@ucsiuniversity.edu.my

Received date: Feb 25, 2014, Accepted date: April 14, 2014, Publication date: April 25, 2014

Copyright: $\odot 2014 \mathrm{Ho} \mathrm{HL}$ et al. This is an open-access article distributed under the terms of the Creative Commons Attribution License, which permits unrestricted use, distribution, and reproduction in any medium, provided the original author and source are credited.

\begin{abstract}
Objective: There has been much concern and immense importance on xylanase due to its potential industrial applications in the manufacturing of pulp and paper, baking, food and beverages, textile and animal feeds production. There are continuously endeavors to turn xylanase into a profitable market with lower production costs using optimum fermentation medium and growth conditions. Thus, the main objectives of this study were to determine the optimum medium formulation and growth conditions for the production of xylanase by Aspergillus brasiliensis ATCC 16404 and to elucidate the correlation of xylanase synthesis with biomass, $\mathrm{pH}$ and protein concentration in submerged fermentation (SmF).
\end{abstract}

Methods: The effect of various carbon sources: sucrose, glucose, maltose, galactose, glycerol, lactose and ethanol and nitrogen sources: yeast extract, urea, peptone, ammonium sulphate, ammonium nitrate, ammonium chloride and sodium nitrate on xylanase activity were examined to obtain the optimum medium formulation for xylanase activity by $A$. brasiliensis. In addition, growth temperatures of 28 to $36^{\circ} \mathrm{C}$ and initial pH medium of 3 to 11 were also examined to elucidate the optimum growth conditions for the production of xylanase.

Results: The highest xylanase activity of $39.567 \mathrm{U} / \mathrm{mL}$ at $72 \mathrm{~h}$ was obtained using sucrose and yeast extract as the optimised carbon and nitrogen sources. Our results also showed that $30^{\circ} \mathrm{C}$ and $\mathrm{pH} 6.5$ were the optimum growth condition of $A$. brasiliensis for xylanase synthesis. $38.528 \mathrm{U} / \mathrm{mL}$ of xylanase activity was observed at $72 \mathrm{~h}$ when the initial $\mathrm{pH}$ medium was adjusted to 5.0 . Nevertheless, when the initial $\mathrm{pH}$ medium was increased to 6.5 , the $\mathrm{xylanase}$ synthesis increased almost $3 \%$ at $72 \mathrm{~h}$.

Conclusion: Hence, in our study, the optimum medium formulation and growth conditions for the production of xylanase by $A$. brasiliensis in $\mathrm{SmF}$ was achieved by growing the fungi in medium containing sucrose and yeast extract with the initial medium $\mathrm{pH} 6.5$ at $30^{\circ} \mathrm{C}$.

Keywords: Submerged fermentation (SmF); Aspergillus brasiliensis; Xylanase; xylan

\section{Introduction}

In recent years, considerable attention has been paid to the use of microorganisms in industrial fermentation processes, especially enzyme production. Usage of xylanase in industry has increased significantly over the years [1]. Several reports were studied on microorganisms producing xylanase in nature and these include yeast, bacteria and fungi [2]. Filamentous fungi, such as Aspergillus [3], Penicillium and Trichoderma [4,5] have been most extensively studied. They have established a great capability of producing a wide range of xylanase where Aspergillus spp remains the fungi of choice for production of xylanase [6]. Filamentous fungi are industrially important producers of xylanase due to the fact that they secrete xylanase into the medium, thus cell disruption is not required. Moreover, xylanase production yield from fungi culture is apparently higher as compared to that of yeast and bacteria cultures. Furthermore, the production of microbial xylanase is also preferred over plant and animal sources because of their availability, structural stability and genetic manipulation [7].
Xylanase (Endo-1,4- $\beta$-xylanase) as the major enzyme involved in the degradation of the hemicelluloses backbone of xylose has been isolated extensively from various microorganisms. Xylanases are known to be inducible enzymes [8]. They are genetically single chain glycoproteins, ranging from 6 to $80 \mathrm{kDa}$, and active between $\mathrm{pH}$ 4.5-6.5 [9]. Xylanases are recognized due to their potential roles in biotechnology field such as pulp and paper industry and daily application of bread making. Application of xylanase in the pulp and paper industry has increased significantly during the past few years [10]. Xylanase is used in the pre-bleaching process to phase out and replace toxic chlorine-based chemicals that are commonly used during the serial processing of bleaching in pulp and paper industry. As a result, this eco-friendly technology involving enzymatic pre-bleaching process of xylanase is able to produce better pulp quality gain of brightness and to minimise the costs of chlorine-based chemicals by reducing the usage of chlorine in the bleaching process. Thus, xylanase plays an effective role in pulp and paper industry due to its simplicity and economical properties.

Due to the potential applications of xylanase in the industries and environment, it is essential to minimize the cost of production by optimising medium formulation and growth conditions of microorganism in submerged fermentation ( $\mathrm{SmF}$ ). $\mathrm{SmF}$ is the 
preferable culture method of microorganisms in liquefied medium. This fermentation is able to produce higher enzymes yield and productivity which it involved lower cost of maintenance and lesser risk of contamination compared to solid state fermentation (SsF) Several studies have been reported on xylanase production involving yeast, bacteria and fungi [2]. Nonetheless, filamentous fungi, especially Aspergillus spp [3] produced higher xylanase activity compared to those of bacterial strains of Bacillus spp [11] and Trichoderma spp [4,5]. As a result, Aspergillus spp have been greatly established with the capability for the synthesis of xylanase. Aspergillus spp is considered as one of the mesophilic microorganisms which require the growth temperatures between 25 to $35^{\circ} \mathrm{C}$. Aspergillus spp are also produced xylanase at the initial $\mathrm{pH}$ medium lower than 7.0.

Even though, Aspergillus spp is preferable microorganism for xylanase production but the study on this enzyme production by Aspergillus brasiliensis was not comprehensive. Therefore in this study, the elucidation of xylanase activity was carried out in "SmF" using $A$. brasiliensis. In order to obtain the optimum production of xylanase by $A$. brasiliensis, this study attempts to elucidate the medium formulation using various carbon sources (sucrose, glucose, maltose, galactose, glycerol, lactose and ethanol) and nitrogen sources (yeast extract, urea, peptone, ammonium sulphate, ammonium nitrate, ammonium chloride and sodium nitrate) at the growth temperatures of 28 to $36^{\circ} \mathrm{C}$ with the adjusted initial $\mathrm{pH}$ medium of 3 to 11 using $\mathrm{SmF}$ in shake flasks culture. Hence, the objectives of the study are to determine the optimum carbon and nitrogen sources for the establishment of medium formulation followed by determination of the optimum initial $\mathrm{pH}$ medium and growth temperature in order to maximize the production of xylanase by $A$. brasiliensis.

\section{Materials and Methods}

\section{Microorganism and inoculum preparation}

Aspergillus brasiliensis ATCC 16404 was maintained on Potato Dextrose Agar (PDA) with $\mathrm{pH} 6.5$ at $4^{\circ} \mathrm{C}$. The inoculums of $A$. brasiliensis was obtained from PDA (pH 6.5) incubated at $30^{\circ} \mathrm{C}$ up to $96 \mathrm{~h}$. Spore suspension was harvested by pouring $0.1 \%$ sterile Tween 80 onto PDA plates. Spore concentration was determined using haemacytometer. Serial dilutions were conducted to obtain spore suspension of $2.0 \times 10^{7}$ spores that used as the standard inoculums size for growth of $A$. brasiliensis in $200 \mathrm{~mL}$ culture medium.

\section{Culture medium and submerged fermentation $(\mathrm{SmF})$}

The composition of culture medium used for xylanase production by $A$. brasiliensis in $\mathrm{SmF}$ was consisted of $(\mathrm{g} / \mathrm{L})$ : carbon source, 200; nitrogen source, 20; $\mathrm{KH}_{2} \mathrm{PO}_{4}, 1.52 ; \mathrm{MgSO}_{4} .7 \mathrm{H}_{2} \mathrm{O}, 0.52$; and $\mathrm{KCl}, 0.52$. The $\mathrm{pH}$ of culture medium was adjusted to 6.5 before autoclaved. Then, A. brasiliensis was cultured at $30^{\circ} \mathrm{C}$ for $120 \mathrm{~h}$ at $150 \mathrm{rpm}$. All of the experiments were duplicated and the mean value was generated from analysis.

\section{Optimisation of medium formulation for xylanase production by one parameter at a time method}

To elucidate the potential use of synthetic defined carbon and nitrogen sources for xylanase production, the study of optimisation for medium formulation was conducted in stepwise manner in this study, starting from the determination of optimum carbon source followed by optimisation of nitrogen source for the production of xylanase by
A. brasiliensis. To determine the optimum carbon source for xylanase production, reducing sugars of glucose, sucrose, galactose, maltose, lactose, glycerol and ethanol were added into the culture medium, respectively. Subsequently, after the parameter of the optimised carbon source was identified, various organic nitrogen sources of yeast extract, urea, peptone and inorganic nitrogen sources of sodium nitrate, ammonium chloride, ammonium sulphate and ammonium nitrate were investigated to determine the optimum nitrogen source for xylanase production, respectively.

\section{Optimisation of growth conditions for xylanase production by one parameter at a time method}

To determine the optimisation of growth conditions, different growth temperatures and $\mathrm{pH}$ medium were investigated for xylanase production by $A$. brasiliensis in SmF. After the optimised medium formulation was obtained, different growth temperatures from 28 to $36^{\circ} \mathrm{C}$ were examined to determine the optimum temperature for the production of xylanase by $A$. brasiliensis. Thereafter, using the optimised medium formulation and the optimum growth temperature, different initial $\mathrm{pH}$ medium from 3 to 11 were elucidated to determine the optimum $\mathrm{pH}$ medium for the production of xylanase by $A$. brasiliensis.

\section{Sampling and analysis}

The samples from the culture flasks were harvested at every regular time interval of $24 \mathrm{~h}$ which started at h-24 and ended at h-120 for analysis throughout the experiments. The sample was centrifuged and cell pellet was used to determine cell growth. Clarified supernatant was collected and used for xylanase and protein assays. The $\mathrm{pH}$ of the culture medium was measured using $\mathrm{pH}$ meter with a glass electrode.

\section{Quantitative of biomass concentration}

Dry cell weight was used to quantify the biomass concentration. The cell pellet was dried in the oven at $80^{\circ} \mathrm{C}$ until constant weight was achieved. Additionally, the spore count of $A$. brasiliensis was determined using haemacytometer. In our study, it is crucial to identify the correlation of xylanase synthesis with the production of biomass involving dry cell weight and spore count, respectively.

\section{Xylanase activity assay}

Xylanase activity was assayed using the method of Bailey et al. [12]. $1 \%$ of xylan in $0.05 \mathrm{M}$ sodium phosphate buffer, $\mathrm{pH} 5.3$ was used as the substrate for xylanase activity. $0.9 \mathrm{~mL}$ of substrate was pipetted into $0.1 \mathrm{~mL}$ of supernatant. The mixture was incubated at $50^{\circ} \mathrm{C}$ for 30 minutes. After incubation, $1.5 \mathrm{~mL}$ of 3,5-dinitrosalicylic acid (DNS) reagent was added and incubated at $90^{\circ} \mathrm{C}$ for 5 minutes. Color changes were observed when xylose was liberated from the reaction occurred between xylan and xylanase. This reducing sugar of xylose was reacted with DNS to form coloration. Then, $0.5 \mathrm{~mL}$ of $40 \%$ Rochelle salt was added to the mixture. The amount of xylose released by the reaction is determined by measuring its absorbance at $575 \mathrm{~nm}$. To quantify the xylanase activity, one unit of enzyme activity corresponds to the amount of enzyme required to release one micromole of xylose per $\mathrm{mL}$ of enzyme extract per minute of reaction under the assay condition. 


\section{Protein assay}

Soluble protein produced by $A$. brasiliensis during xylanase synthesis was determined according to Lowry et al. [13] using Bovine Serum Albumin (BSA) as the standard. The absorbance reading of samples was measured using a spectrophotometer at $750 \mathrm{~nm}$.

\section{Results and Discussion}

\section{Xylanase production by Aspergillus brasiliensis in submerged fermentation $(\mathrm{SmF})$}

The aim of the present study is to elucidate xylanase activity from A. brasiliensis by optimising their parameters in medium formulation and growth conditions. This study was carried out using SmF over a fermentation period of $120 \mathrm{~h}$. The addition of carbon and nitrogen sources is a general practice to improve the nutritional requirement for the growth and production of xylanase by $A$. brasiliensis. Therefore, in the study, various carbon and nitrogen sources were investigated to obtain the optimum medium formulation. These exerted a momentous effect on xylanase synthesis. Likewise, xylanase synthesis by $A$. brasiliensis was also highly affected by the growth conditions including growth temperature and $\mathrm{pH}$ medium.

\section{Effect of different defined carbon sources on xylanase production}

The profile of xylanase activity by $A$. brasiliensis was observed from 24 to $120 \mathrm{~h}$ from different carbon sources of glucose, maltose, sucrose, galactose, lactose, glycerol and ethanol and the mean values are presented in Figure 1. It is obvious that at the beginning of fermentation period, $A$. brasiliensis produced small amounts of xylanase from all carbon sources, and as the time of fermentation proceeded, majority of xylanase synthesis from different carbon sources were increased gradually up to 72 and only a few were extended to $96 \mathrm{~h}$. Thereafter, a decreasing trend was observed. The maximum xylanase activity for sucrose, maltose, lactose, galactose and glucose was detected at the end of logarithmic phase until stationary phase of growth up to $96 \mathrm{~h}$. Apparently, our research findings indicated that the majority of xylanase production by $A$. brasiliensis commenced at the lower rate during the logarithmic phase of growth, however, it exerted its maximum synthesis during the stationary phase of growth. Thus, the complete time course study of xylanase activity and biomass production is necessary to determine the efficacy of growth and subsequently the xylanase formation and their correlation with biomass production.

In our study, the growth of $A$. brasiliensis was slower at the beginning of fermentation process with lower productivity of xylanase, but, the enzyme secretion was speeded up after prolonged fermentation until it reached its stationary phase. Using sucrose as the carbon source, the xylanase activity reached to $32.940 \mathrm{U} / \mathrm{ml}$ at $24 \mathrm{~h}$ of $\mathrm{SmF}$, thereafter it increased to $34.877 \mathrm{U} / \mathrm{mL}$ at $48 \mathrm{~h}$ and achieved its maximum activity of $39.567 \mathrm{U} / \mathrm{mL}$ at $72 \mathrm{~h}$ as shown in Figure 1 . Among the different carbon sources studied, sucrose was found to be the best preferred and most easily consumable carbon source for the production of xylanase. This result was similar to that reported by Seyis and Aksoz [5], when different carbon sources of sucrose, maltose and lactose were added separately to the medium to determine their effects on xylanase production. Nevertheless, they reported that the maximum peak of xylanase activity was observed in the medium containing sucrose. The high yield of this enzyme in sucrose was probably because of the ease absorption of sucrose to the fungi [14]. Sucrose is more preferable sugar compared to others especially for Aspergillus spp because they have an extra potent cellular myceliumbound invertase that is actively and rapidly hydrolysed sucrose [15]

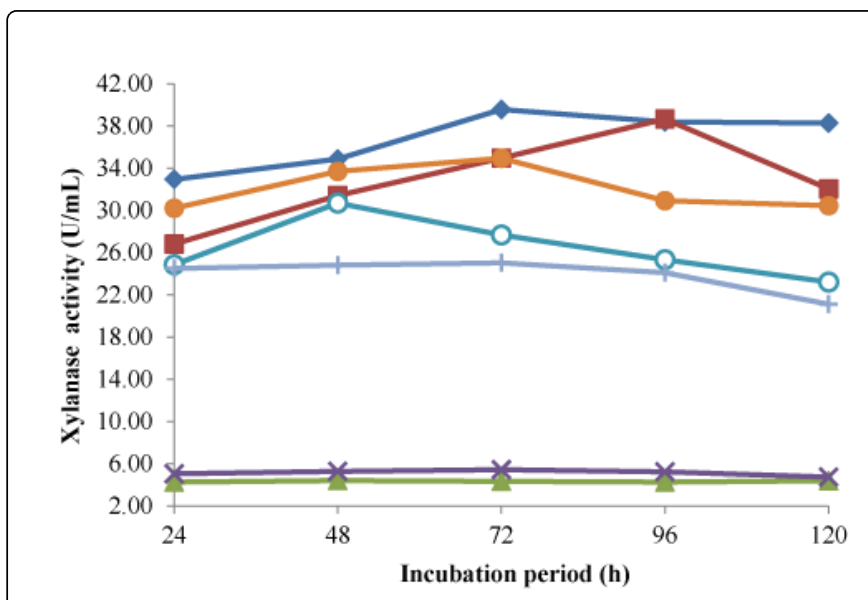

Figure 1: Time course of xylanase production of Aspergillus brasiliensis in SmF using different carbon sources. Xylanase activity was measured in the culture supernatant and the values are means of duplicated determination. Sucrose $(\bullet)$; maltose (•); ethanol $(\boldsymbol{\Delta})$; glycerol $(\times)$; galactose $(\circ)$; glucose $(\bullet)$; lactose $(+)$.

As the fermentation prolonged, the xylanase activity dropped gradually to $38.278 \mathrm{U} / \mathrm{mL}$ at $120 \mathrm{~h}$ using sucrose as the carbon source. This was due to the fact that $A$. brasiliensis attained to the death phase of its growth as it moved towards $120 \mathrm{~h}$ after the nutrients depletion and accumulation of toxic products occurred in SmF. In other study conducted by Sati and Bisht [16], the production of xylanase by fungi, Tetracladium marchalianum was examined using sucrose and glucose as carbon sources. Interestingly, sucrose exerted higher xylanase activity compared to glucose, producing $107 \mathrm{U} / \mathrm{mL}$ of xylanase activity. They also reported xylanase activity of $90 \mathrm{U} / \mathrm{mL}$ was observed when Tetracheatum elegans cultured at the optimum conditions.

The maximum xylanase activity from maltose, glucose, galactose and lactose was $38.670,34.951,30.706$ and $25.031 \mathrm{U} / \mathrm{mL}$, respectively. It was possible that these carbon sources were utilised rapidly for the synthesis of cellular materials in metabolism. Thereafter, little would be available as carbon and energy source for xylanase synthesis. According to Simoes et al. [2], both maltose and lactose possessed lower production of xylanase, producing 17.8 and $19.5 \mathrm{U} / \mathrm{mL}$ by Aspergillus niger and Penicillium implicatum, respectively. On the other hand, the microorganism was in the least efficient of the xylanase activity when it was grown on culture medium containing ethanol as the carbon source. Therefore, the lowest xylanase activity of only $4.407 \mathrm{U} / \mathrm{mL}$ at $48 \mathrm{~h}$ was observed in medium formulation containing ethanol. This was due to the least biomass production of $A$. brasiliensis occurred using ethanol. Based on our results, we anticipated that glycerol was one of the least easily consumable carbon sources (Figure 2). Even though, glycerol showed slightly higher enzyme activity of $5.443 \mathrm{U} / \mathrm{mL}$ as compared to ethanol, yet the activity was still unfortunately considered very low for xylanase production as a result of poor metabolism ability of $A$. brasiliensis in glycerolcontaining medium. Practically, very less xylanase was produced when glycerol, soluble starch and cellulose were used as the carbon sources. 
Citation: Ho HL, Hood JS (2014) Optimisation of Medium Formulation and Growth Conditions for Xylanase Production by Aspergillus brasiliensis in Submerged Fermentation (SmF). J Biodivers Biopros Dev 1: 102. doi:10.4172/2376-0214.1000102

Page 4 of 13

Hence, in our study, both glycerol and ethanol were not the suitable substrates for the xylanase synthesis in $A$. brasiliensis.

Therefore, it could be concluded that the optimised carbon source for medium formulation to produce xylanase by $A$. brasiliensis is sucrose. These results were similar to those reported by Rifaat et al. [17] when various carbon sources were investigated to obtain the maximum xylanase activity by Streptomyces species. According to Rifaat et al. [17], they obtained the maximum xylanase activity of 15.52 $\mathrm{U} / \mathrm{mL}$ by Streptomyces chromofuscus when sucrose was used as the carbon source compared to only $10.26 \mathrm{U} / \mathrm{mL}$ of xylanase activity in glucose-containing medium. In addition, Streptomyces albus produced lesser xylanase activity of $9.01 \mathrm{U} / \mathrm{mL}$ using glucose compared to $12.22 \mathrm{U} / \mathrm{mL}$ of activity when observed in medium containing sucrose according to Rifaat et al. [17].

During fermentation process, different carbon sources exhibited different significant effects on biomass concentration as shown in Figure 2. Apparent most of the logarithmic phase of growth started from 24 up to $72 \mathrm{~h}$, thereafter, stationary phase occurred shortly to 96 $\mathrm{h}$ before depleted subsequently. Dried cells reached a maximum weight of $190.500 \mathrm{~g} / \mathrm{L}$ at $72 \mathrm{~h}$ using sucrose followed by 145.5, 107.0, 90.0 and $60.5 \mathrm{~g} / \mathrm{L}$ from maltose, glucose, galactose and lactose, respectively (Figure $2 \mathrm{~A}$ ). An obvious decrease in the dry cell weight was observed after $96 \mathrm{~h}$. This was confirmed by the study of Asha Augustine et al. [18], who observed a decrease in dry cell weight of Aspergillus niger as the fermentation progressed as a result of gradual utilisation of substrate for biomass and energy production. On the other hand, very low dry cell weight of only 32.5 and $17.5 \mathrm{~g} / \mathrm{L}$ were attained at $72 \mathrm{~h}$ of fermentation for medium containing less accessible carbon sources of glycerol and ethanol, indicating the growth of $A$. brasiliensis was extensively poor where these carbon sources were less preferable to utilise and hydrolyse for cell metabolism and xylanase formation. Thus, both produced only 5.443 and $4.346 \mathrm{U} / \mathrm{mL}$ of xylanase activity at $72 \mathrm{~h}$, respectively.

In Figure $2 \mathrm{~B}$, the maximal spore count of $7.5 \times 10^{8}$ spores $/ \mathrm{mL}$ was observed in medium containing sucrose after $72 \mathrm{~h}$. The remaining carbon sources of maltose, glucose, lactose and galactose produced 5.6 $\times 10^{8}, 4.7 \times 10^{8}, 2.9 \times 10^{8}$ and $2.5 \times 10^{8}$ spores $/ \mathrm{mL}$, respectively. Conversely, glycerol and ethanol possessed again, the lowest spore count in our study. This explains why very little of xylanase was produced throughout the fermentation. Based on the result findings, xylanase synthesis was apparently increased according to biomass production. In our study, the higher the production of biomass, the larger amount of xylanase produced. Altaf et al. [19] confirmed that the production of metabolites by different microorganisms was greatly influenced by their growth, which was determined by the presence of different carbon sources that provide the nutritional requirement for the growth of microorganisms. Moreover, our results also indicate the medium preference of $A$. brasiliensis was depending on their carbon sources and this was confirmed by the study of D'Souza-Ticlo et al [20]. The scientists observed high concentrations of an easy consumable carbon source such as glucose resulted in a positive effect on biomass accumulation. In addition, the study by Carlsen et al. [21] also stated that enzyme production was closely connected to the growth of the fungi that required energy from the oxidation of medium components consisted of carbon and nitrogen sources.
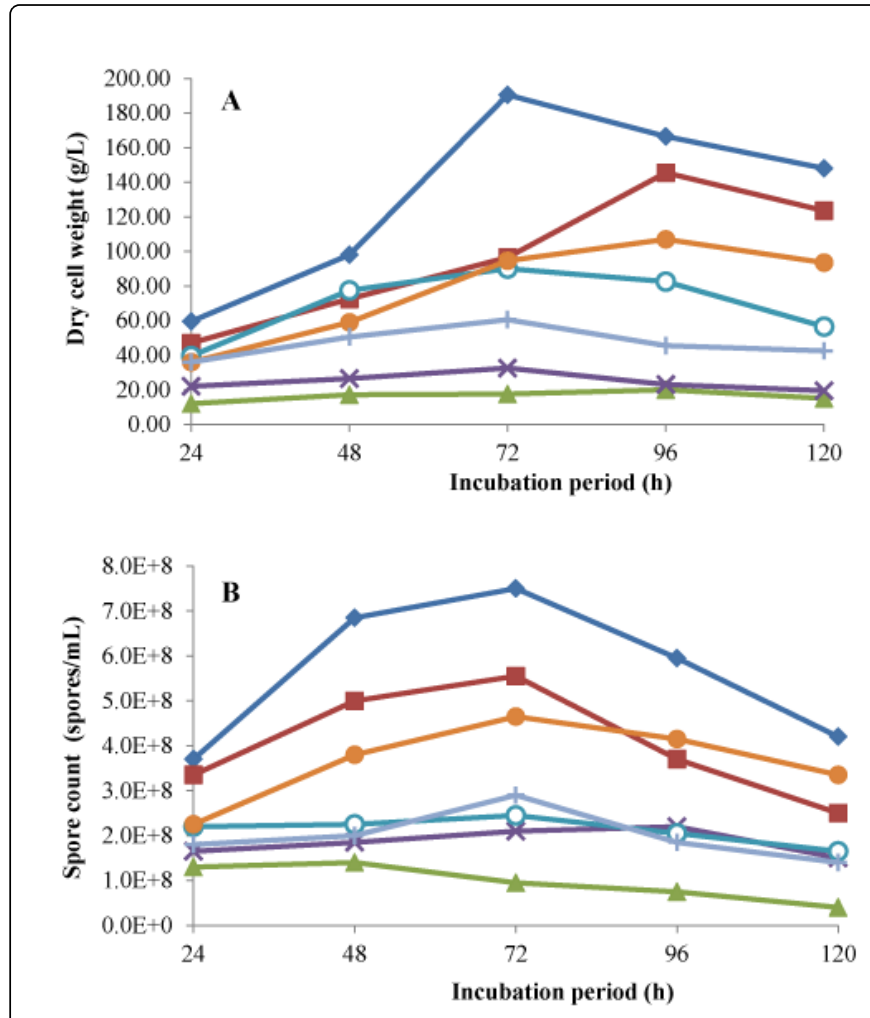

Figure 2: Growth profile of Aspergillus brasiliensis using different carbon sources in SmF: dry cell weight (A) and spore count (B). The values are means of duplicated determination. Sucrose ( $\bullet$; maltose $(\bullet)$; ethanol $(\boldsymbol{\Delta})$; glycerol $(\times)$; galactose $(0)$; glucose $(\bullet)$; lactose (+).

Filamentous fungi have been well known for the secretion of huge amounts of extracellular protein thus making them to be well accepted as the important microbial strain for the industrial production of various enzymes. Lowry method was used to investigate the concentration of extracellular protein by $A$. brasiliensis in culture during xylanase synthesis. By using sucrose as the carbon source, the maximum protein concentration of $0.028 \mathrm{~g} / \mathrm{mL}$ was observed after 96 $\mathrm{h}$ as shown in Figure 3(A). The lowest protein concentration of 0.003 $\mathrm{g} / \mathrm{mL}$ at $72 \mathrm{~h}$ was obtained for both ethanol and glycerol due to the retarded growth of the fungi. There was not much difference in the remaining carbon sources with that of sucrose. Maltose, galactose, glucose and lactose produced $0.029,0.027,0.021$ and $0.020 \mathrm{~g} / \mathrm{mL}$ of protein concentration, respectively. In the experiments, the $\mathrm{pH}$ medium decreased rapidly from an initial $\mathrm{pH}$ of 6.5 as shown in Figure 3(B). Sucrose which produced the highest xylanase activity decreased the $\mathrm{pH}$ medium from 6.5 to 4.52 at $72 \mathrm{~h}$, where the maximum production of xylanase was observed. Similarly, maltose, glucose, galactose, lactose and glycerol decreased their $\mathrm{pH}$ medium to 4.51, $4.83,5.9,4.83$ and 6.16 , respectively during their optimum xylanase activity. However, the $\mathrm{pH}$ medium of 6.55 in the medium containing ethanol remained constant up to $120 \mathrm{~h}$. 


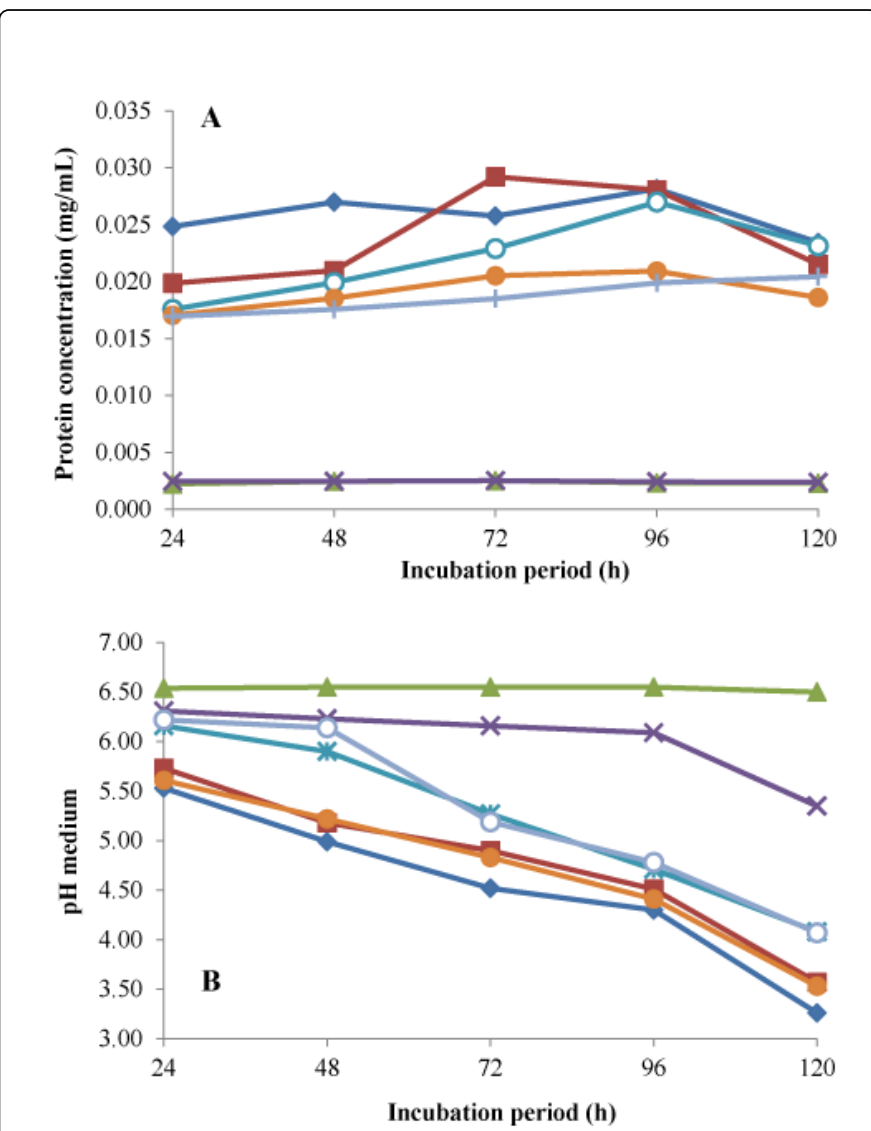

Figure 3: Time course of protein production by Aspergillus brasiliensis (A) and $\mathrm{pH}$ medium profile (B) of Aspergillus brasiliensis using different carbon sources in SmF. The values are means of duplicated determination. Sucrose $(\bullet)$; maltose $(\bullet)$; ethanol ( $\mathbf{\Delta})$; glycerol $(\times)$; galactose $(\circ)$; glucose $(\bullet)$; lactose $(+)$.

On the other hand, urea as the organic nitrogen source did not seem to significantly enhance the xylanase activity by $A$. brasiliensis in our study. Urea has been reported by many studies as one of the organic compounds with the chemical formula of $\left(\mathrm{NH}_{2}\right)_{2} \mathrm{CO}$ that produced the lowest xylanase activity. Bakri et al. [28] investigated xylanase production by Cochliobolus sativus using different nitrogen sources including potassium nitrate, sodium nitrate, urea, peptone and yeast extract. Nevertheless, urea produced the lowest xylanase activity. Similar finding were also found by Goyal et al. [29] where urea was detected to produce the lowest xylanase activity of $1280 \mathrm{U} / \mathrm{L}$ by Trichoderma viride, compared to 1599, 2026, 2239 and $2506 \mathrm{U} / \mathrm{L}$ from ammonium nitrate, ammonium chloride, ammonium sulphate and sodium nitrate, respectively. Likewise, in our study, the lowest xylanase activity of $11.348 \mathrm{U} / \mathrm{mL}$ at $120 \mathrm{~h}$ was also observed when urea was used in the medium as the nitrogen source.

\section{Effect of different nitrogen sources on xylanase production}

Different organic and inorganic nitrogen sources exert critical influential impact on their ability to enhance growth of microorganisms as well as enzymes production. The optimisation of nitrogen source in the fermentation is equally essential as carbon source. Thus, the optimisation of nitrogen source was studied for its effect on xylanase activity. By maintaining the carbon source at the optimized condition, various organic nitrogen sources: yeast extract, peptone, urea and inorganic nitrogen sources: sodium nitrate, ammonium chloride, ammonium sulphate and ammonium nitrate were elucidated from 24 to $120 \mathrm{~h}$ for its optimum xylanase production as shown in Figure 4. In case of organic nitrogen sources, the maximum xylanase activity of $39.567 \mathrm{U} / \mathrm{mL}$ at $72 \mathrm{~h}$ was obtained from yeast extract. This might be due to better utilisation of nutrients by $A$. brasiliensis. Moreover, nitrogen source resulted in the efficient growth of Aspergillus niger and its enhancement of xylanase activity [22]. Then, the xylanase activity from the medium containing yeast extract was slowly decreased and reached to $38.278 \mathrm{U} / \mathrm{mL}$ at $120 \mathrm{~h}$. On the other hand, peptone resulted in considerable increase of xylanase activity up to $35.997 \mathrm{U} / \mathrm{mL}$ at $72 \mathrm{~h}$. Among several organic and inorganic nitrogen sources used for production of xylanase by Aspergillus flavus, yeast extract and peptone were observed to be the most recommended nitrogen sources [23]. These results were similar to those reported by Kumar et al. [24]. When they investigated different organic nitrogen sources for xylanase synthesis by Bacillus pumilus, yeast extract was found to be the best nitrogen source for xylanase activity, producing $128.07 \mathrm{U} / \mathrm{mL}$. Aqeel and Umar [25] reported that organic nitrogen sources such as peptone and yeast extract usually had the stimulating effect on the production of enzyme. Pal and Kaushik [26] studied the effect of various nitrogen sources on the growth of Rhizoctonia solani and the highest xylanase activity was observed from the organic nitrogen sources of yeast extract and peptone. According to Li et al. [27], appreciable xylanase activity of $42.54 \mathrm{U} / \mathrm{mL}$ was obtained by Streptomyces chartreusis when cultured in medium containing yeast extract as nitrogen source.

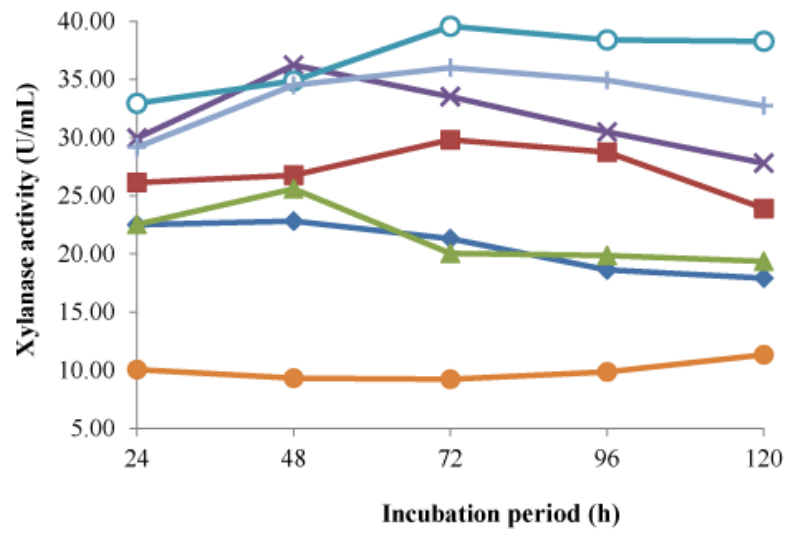

Figure 4: Time course of xylanase production of Aspergillus brasiliensis using different nitrogen sources in SmF. Xylanase activity was measured in the culture supernatant, and values are means of duplicated determination. Ammonium chloride ( $\bullet$ ); ammonium nitrate $(\cdot)$; ammonium sulphate $(\boldsymbol{\Delta})$; sodium nitrate $(\times)$; yeast extract $(\circ)$; urea $(\bullet)$; peptone $(+)$.

On the other hand, $\mathrm{NaNO}_{3}$ as the inorganic nitrogen source in the growth medium obtained a slightly lower xylanase activity of 36.22 $\mathrm{U} / \mathrm{mL}$ compared to that of yeast extract. This value was obtained at 48 $\mathrm{h}$ and the activity gradually decreased starting from $72 \mathrm{~h}$, unlike yeast extract where the highest activity was observed at $72 \mathrm{~h}$. This could be the strongest reason for favoring yeast extract as the optimum and most suitable nitrogen source for xylanase production by $A$. 
brasiliensis in our study. Based on our results, all inorganic nitrogen sources produced reasonable xylanase activity but lower than the organic nitrogen sources. Abdel-Naby et al. [30] stated that ammonium compounds such as $\mathrm{NH}_{4} \mathrm{NO}_{3},\left(\mathrm{NH}_{4}\right)_{2} \mathrm{SO}_{4}$ and $\mathrm{NH}_{4} \mathrm{Cl}$ showed the moderate levels of xylanase production. In addition, some studies even show a very low amount of enzyme produced in the presence of inorganic nitrogen [24]. Thus, in our study, inorganic nitrogen sources of $\mathrm{NH}_{4} \mathrm{NO}_{3},\left(\mathrm{NH}_{4}\right)_{2} \mathrm{SO}_{4}$ and $\mathrm{NH}_{4} \mathrm{Cl}$ produced xylanase activity of $29.809 \mathrm{U} / \mathrm{mL}$ at $72 \mathrm{~h}, 25.591 \mathrm{U} / \mathrm{mL}$ at $48 \mathrm{~h}$ and $22.824 \mathrm{U} / \mathrm{mL}$ at $48 \mathrm{~h}$, respectively. Rifaat et al. [17] investigated and compared various organic and inorganic nitrogen sources for xylanase activity by Streptomyces species. Likewise, the highest activity of xylanase was produced using yeast extract followed by inorganic nitrogen sources. According to Rifaat et al. [17], they reported that xylanase activity from Streptomyces albus and Streptomyces chromofuscus was the highest when yeast extract was used as the nitrogen source, producing 79.21 and $90.01 \mathrm{U} / \mathrm{mL}$ followed by 76.56 and $87.31 \mathrm{U} / \mathrm{mL}$ from $\left(\mathrm{NH}_{4}\right)_{2} \mathrm{SO}_{4} ; 74.49$ and $84.26 \mathrm{U} / \mathrm{mL}$ from $\mathrm{NaNO}_{3} ; 69.50$ and $80.45 \mathrm{U} / \mathrm{mL}$ from $\mathrm{NH}_{4} \mathrm{NO}_{3}$, respectively.

Based on our findings, xylanase activity using inorganic nitrogen sources started reducing their activity after $48 \mathrm{~h}$ whereas culture medium with organic nitrogen sources continued producing xylanase up to $72 \mathrm{~h}$ and gradually decreased from $96 \mathrm{~h}$ which corresponds to the fact that organic nitrogen sources stimulate xylanase activity [31]. Precisely, many scientists recommended yeast extract and peptone as the optimised nitrogen sources [32-34]. The observations of high xylanase activity obtained could be due to their enormous amount of amino acids, peptides, vitamins, trace elements and mineral salts available in these nitrogen sources [14]. In conclusion, yeast extract is the optimised nitrogen source of medium formulation for xylanase production by $A$. brasiliensis. Furthermore, our results agreed with many studies that carried out to identify the optimum xylanase activity by different microorganisms. Tallapragada and Venkatesh [35] studied the effect of beef extract, meat extract, peptone, yeast extract, ammonium sulphate, ammonium nitrate and sodium nitrate on growth of Aspergillus niger and hence, yeast extract produced higher xylanase activity of $14.37 \mathrm{U} / \mathrm{mL}$. Likewise, Bajaj et al. [36] observed the optimum xylanase activity of $6500 \mathrm{U} / \mathrm{L}$ by Streptomyces spp from the medium containing yeast extract when compared to peptone and soybean meal. Similarly, Singh et al. [37] also reported that yeast extract showed the highest xylanase activity of $723.78 \mathrm{U} / \mathrm{mL}$ by Coprinellus disseminates when compared to the other complex nitrogen sources such as beef extract, malt extract, peptone and soybean meal, respectively.

Dry cell weight of $190.5 \mathrm{~g} / \mathrm{L}$ at $72 \mathrm{~h}$ was obtained in medium containing yeast extract followed by $\mathrm{NH}_{4} \mathrm{NO}_{3}$, peptone, $\mathrm{NaNO}_{3}$, $\left(\mathrm{NH}_{4}\right)_{2} \mathrm{SO}_{4}$ and $\mathrm{NH}_{4} \mathrm{Cl}$ which produced $156.5,147.5,135.0,131.0$ and $117.5 \mathrm{~g} / \mathrm{L}$, respectively (Figure $5 \mathrm{~A}$ ). The lowest dry cell weight of 57.5 $\mathrm{g} / \mathrm{L}$ was observed when cultured with urea at $96 \mathrm{~h}$. Based on our results, we anticipated that when urea dissolved in aqueous medium, it formed ammonium bicarbonate and hydroxide ions: $\left(\mathrm{NH}_{2}\right)_{2} \mathrm{CO}+$ $2 \mathrm{H}_{2} \mathrm{O} \rightarrow \mathrm{NH}_{4} \mathrm{HCO}_{3}+\mathrm{OH}^{-}$. Once the $\mathrm{pH}$ medium was adjusted to 6.5 with acid, $\mathrm{NH}_{4}{ }^{+}, \mathrm{Cl}^{-}, \mathrm{H}_{2} \mathrm{O}$ and $\mathrm{HCO}_{3}{ }^{-}$were formed abundantly in the medium. At the very beginning of the fermentation at $0 \mathrm{~h}$, the $\mathrm{pH}$ medium obtained after autoclaved was already as high as 9.5, due to the present of bicarbonate ion $\left(\mathrm{HCO}_{3}{ }^{-}\right)$that was alkaline, shifted the $\mathrm{pH}$ medium upward until it reached the circumstances where the enormous degree of alkalinity became too toxic to some microorganisms including $A$. brasiliensis. Furthermore, small amount of ammonium ion in the medium was tended to convert to other chemical constituents such as ammonia, which was one of the basic molecules. This gas volatilized to the empty space in the culture flask. As the fermentation prolonged, ammonia gas that dissolved in the liquid medium was continuously maintained a solution rich with alkaline condition, resulting the $\mathrm{pH} 9.5$ throughout our study (Figure 7). As a result, the fungi struggled to grow, hence it produced the lowest dry cell weight and the minimum xylanase production when cultured in medium containing urea.

On the other hand, Arrizon and Gschaedler [38] compared the production of biomass with and without nitrogen source and hence, higher production of biomass was obtained by adding nitrogen source compared to medium without nitrogen source. Oshoma et al. [22] confirmed that higher biomass of Aspergillus niger was obtained with nitrogen supplementation and yeast extract gave the highest biomass yield. This indicates that nitrogen source is essential in the medium formulation where it influences the growth of microorganisms. Similarly, the optimum spore count of $7.5 \times 10^{8}$ spores/mL was observed in yeast extract at $72 \mathrm{~h}$ as shown in Figure 5B. However, the lowest spore count of $1.6 \times 10^{8}$ spores $/ \mathrm{mL}$ at $72 \mathrm{~h}$ was found when urea was used as the nitrogen source. The spore count for the remaining nitrogen sources of peptone, $\mathrm{NaNO}_{3},\left(\mathrm{NH}_{4}\right)_{2} \mathrm{SO}_{4}, \mathrm{NH}_{4} \mathrm{NO}_{3}$ and $\mathrm{NH}_{4} \mathrm{Cl}$ were found to be $5.8 \times 10^{8}, 4.1 \times 10^{8}, 3.5 \times 10^{8}, 3.0 \times 10^{8}$ and $3.0 \times 10^{8}$ spores $/ \mathrm{mL}$, respectively. These results agreed with $\mathrm{Pal}$ and Kaushik [26] who studied the maximum growth of Rhizoctonia solani. This fungi showed the maximum biomass growth in medium containing yeast extract followed by peptone and sodium nitrate whereas the lowest growth was observed using ammonium chloride [26].

According to Abdel-Naby et al. [30], xylanase activity was apparently optimum during the active growth of Aspergillus niger. They detected that there was a close linear relationship between xylanase formation and the increase of extracellular protein produced by $A$. niger [30]. In our study, the highest protein concentration of $0.028 \mathrm{~g} / \mathrm{mL}$ were secreted by $A$. brasiliensis in medium containing yeast extract at $96 \mathrm{~h}$ followed by peptone, $\mathrm{NaNO}_{3}, \mathrm{NH}_{4} \mathrm{NO}_{3}$, $\left(\mathrm{NH}_{4}\right)_{2} \mathrm{SO}_{4}$ and $\mathrm{NH}_{4} \mathrm{Cl}$, producing $0.015,0.009,0.007,0.005$ and 0.003 $\mathrm{g} / \mathrm{mL}$, respectively. However, protein concentration of $0.002 \mathrm{~g} / \mathrm{mL}$ with medium containing urea was very low as compared to the medium containing other nitrogen sources. This might due to the insufficient nutrients in urea such as amino acids, peptides, vitamins and other nutrients required for growth and enzymes formation. Figure 6 illustrates the protein concentration obtained from organic and inorganic nitrogen sources during xylanase synthesis by $A$. brasiliensis.

The $\mathrm{pH}$ medium of inorganic nitrogen sources as shown in Figure 7 reduced more rapidly as compared to the organic nitrogen sources even though, the xylanase activity remained low. Furthermore, nitrogen sources influence the $\mathrm{pH}$ of the medium during fermentation process [39]. The results obtained in our study were corresponded with Ikenebomeh and Chikwendu [40] where the nitrogen supplements were managed to increase enzymes production in the medium. The $\mathrm{pH}$ of the culture medium, initially adjusted to $\mathrm{pH} 6.5$, reduced to $\mathrm{pH} 4.52$ at $72 \mathrm{~h}$ using yeast extract as the nitrogen source where the maximum xylanase activity was achieved. Towards the end, the $\mathrm{pH}$ decreased to 3.26 . Medium with peptone decreased the $\mathrm{pH}$ medium gradually. At its highest xylanase activity, the $\mathrm{pH}$ value was 5.38. On the other hand, $\mathrm{pH}$ of medium with urea increased instead, to 9.49 at $120 \mathrm{~h}$ from the initial $\mathrm{pH}$ of 6.5 . It was also observed in the previous study that increase in $\mathrm{pH}$ of the medium solution was 
Citation: Ho HL, Hood JS (2014) Optimisation of Medium Formulation and Growth Conditions for Xylanase Production by Aspergillus brasiliensis in Submerged Fermentation (SmF). J Biodivers Biopros Dev 1: 102. doi:10.4172/2376-0214.1000102

Page 7 of 13

accompanied by decrease in production of xylanase [41]. Hence, this explains why xylanase activity was the lowest when the $\mathrm{pH}$ medium for urea increased up to 9.49. As for inorganic nitrogen sources, $\mathrm{pH}$ at the optimum xylanase activity were $3.72,2.705,2.61$ and 2.135 with respect to $\mathrm{NaNO}_{3},\left(\mathrm{NH}_{4}\right)_{2} \mathrm{SO}_{4}, \mathrm{NH}_{4} \mathrm{Cl}$ and $\mathrm{NH}_{4} \mathrm{NO}_{3}$, respectively. It was reported by Stanbury et al. [42] that sometimes, ammonium salts such as ammonium sulfate produce and enhance gradually the acidity in the medium as fermentation prolonged.

\section{Effect of different growth temperatures on xylanase production}

Different Aspergillus spp were grown at different growth temperatures. The growth temperature is one of the important parameters to determine the performance of xylanase in SmF. Most filamentous fungi are mesophilic. They require the optimal growth temperatures between 25 and $35^{\circ} \mathrm{C}$, although some species thrive at $50^{\circ} \mathrm{C}[43,44]$. Aspergillus niger was reported to grow best at 25 to $30^{\circ} \mathrm{C}$. At the higher temperatures than the optimum, the heat transfer between molecules is high and thus, it leads to enzymes denaturation and inhibition. In addition, heat destroys the properties of the nutrients in raw materials and therefore, it decreases the productivity of enzymes in fermentation. Meanwhile, the lower temperatures lead to the lower metabolic activity [45]. In our study, the determination of the optimum growth temperature for xylanase activity by $A$. brasiliensis at temperature ranges of 28 to $36^{\circ} \mathrm{C}$ from 24 to $120 \mathrm{~h}$ of $\mathrm{SmF}$ is shown in Figure 8. Rahman et al. [46] reported the best temperature range for the production of xylanase by fungi is usually occurred from 20 to $30^{\circ} \mathrm{C}$. However, other studies indicated that the optimal temperatures for the production of most fungal xylanases occurred at the range between 30 and $50^{\circ} \mathrm{C}$ [34-47]. When experimented at these temperatures, xylanase showed its maximum activity occurred at $30^{\circ} \mathrm{C}$. This observation coincides with those reported in a previous study where xylanase activity was found to be optimum at $30^{\circ} \mathrm{C}$ [48]. Moreover, at temperature above $30^{\circ} \mathrm{C}$, the fungi showed a declining trend in xylanase activity [48].

In this study, the optimum xylanase activity at $30^{\circ} \mathrm{C}$ reached 38.528 $\mathrm{U} / \mathrm{mL}$ after incubating for $72 \mathrm{~h}$ and gradually decreased to 33.946 $\mathrm{U} / \mathrm{mL}$ at the end of fermentation period. In addition, Ahmad et al. [9] reported that Aspergillus niger is mesophillic in nature and thus performed best at $30^{\circ} \mathrm{C}$, while higher temperatures exerted negative impact on the growth of the fungi, resulting in reduced xylanase synthesis. At the higher or lower than the optimum temperature, the growth of Aspergillus niger was inhibited and hence, the xylanase activity was decreased [46-49]. Similarly, various studies proved that $30^{\circ} \mathrm{C}$ was the best growth temperature for xylanase activity by Aspergillus spp [50-52]. The highest xylanase activity of $276 \mathrm{U} / \mathrm{mL}$ reported by Bailey et al. [53] was observed when Aspergillus foetidas incubated at $30^{\circ} \mathrm{C}$. Moreover, Aspergillus niger produced the xylanase activity of $69.88 \mathrm{U} / \mathrm{mL}$ when incubated at $30^{\circ} \mathrm{C}$ [54]. In addition, other fungi was also produced high xylanase activity as observed by Gupta et al. [54] where $69.88 \mathrm{U} / \mathrm{mL}$ of xylanase activity was achieved when they cultured Fusarium solani at $30^{\circ} \mathrm{C}$.

At the temperature of $32^{\circ} \mathrm{C}$, the xylanase activity was found to be slightly lower than that at $30^{\circ} \mathrm{C}$. Xylanase activity of $36.409 \mathrm{U} / \mathrm{mL}$ was achieved after incubating for $48 \mathrm{~h}$ then started to reduce to 32.562 $\mathrm{U} / \mathrm{mL}$ at $120 \mathrm{~h}$ when incubated at $32^{\circ} \mathrm{C}$. On the other hand, a yield of $35.241 \mathrm{U} / \mathrm{mL}$ at $96 \mathrm{~h}$ and $33.723 \mathrm{U} / \mathrm{mL}$ at $72 \mathrm{~h}$ of xylanase activity was obtained with the respect to $28^{\circ} \mathrm{C}$ and $34^{\circ} \mathrm{C}$. The highest xylanase activity of $38.528 \mathrm{U} / \mathrm{mL}$ was being obtained at growth temperature of $30^{\circ} \mathrm{C}$ and the lowest value of $32.245 \mathrm{U} / \mathrm{mL}$ achieved at growth temperature of $36^{\circ} \mathrm{C}$, confirms the observations obtained by Prasertsan et al. [55] that xylanase production decreased as the temperature increased. In addition, the rise in temperature may cause the protein denaturation and hence, leading to the reduction of xylanase activity.
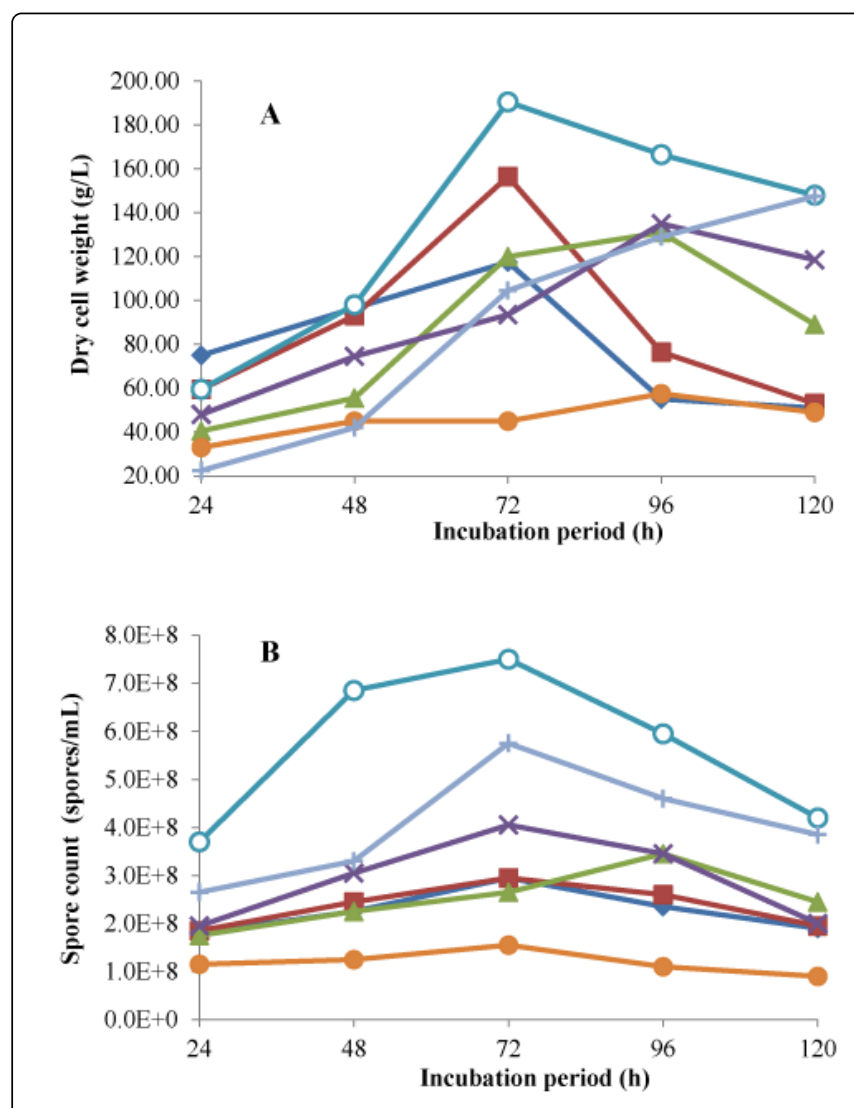

Figure 5: Growth profile of Aspergillus brasiliensis. dry cell weight (A) and spore count (B) using different nitrogen sources in SmF. The values are means of duplicated determination. Ammonium chloride ( $)$; ammonium nitrate $(\cdot)$; ammonium sulphate $(\boldsymbol{\Delta})$; sodium nitrate $(\times)$; yeast extract $(\circ)$; urea $(\bullet)$; peptone $(+)$.

Therefore, the lowest xylanase activity at $72 \mathrm{~h}$ was observed in culture medium incubated at $36^{\circ} \mathrm{C}$. These observations coincide with those in a previous study reported by Gupta et al. [54] when they investigated Fusarium solani for xylanase production at different growth temperatures. According to Gupta et al. [54], the maximum xylanase production of approximately 60 and $70 \mathrm{U} / \mathrm{mL}$ were obtained at $30^{\circ} \mathrm{C}$ by free and immobilised cells of Fusarium solani. However, when growth temperature increased to $35^{\circ} \mathrm{C}$, the xylanase activity dropped to 40 and $20 \mathrm{U} / \mathrm{mL}$ by free and immobilised cells of Fusarium solani, respectively [54]. 
Citation: Ho HL, Hood JS (2014) Optimisation of Medium Formulation and Growth Conditions for Xylanase Production by Aspergillus brasiliensis in Submerged Fermentation (SmF). J Biodivers Biopros Dev 1: 102. doi:10.4172/2376-0214.1000102

Page 8 of 13

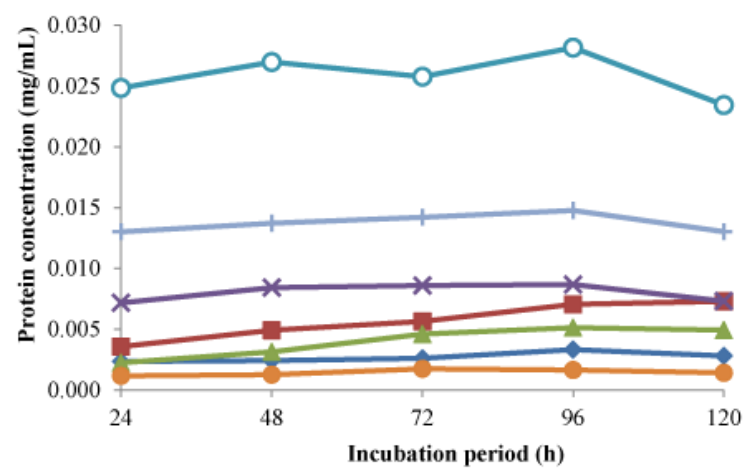

Figure 6: Protein production by Aspergillus brasiliensis using different nitrogen sources in SmF. The values are means of duplicated determination. Ammonium chloride ( $\bullet$; ammonium nitrate $(\cdot)$; ammonium sulphate $(\boldsymbol{\Delta})$; sodium nitrate $(\times)$; yeast extract (०); urea (•); peptone $(+)$.

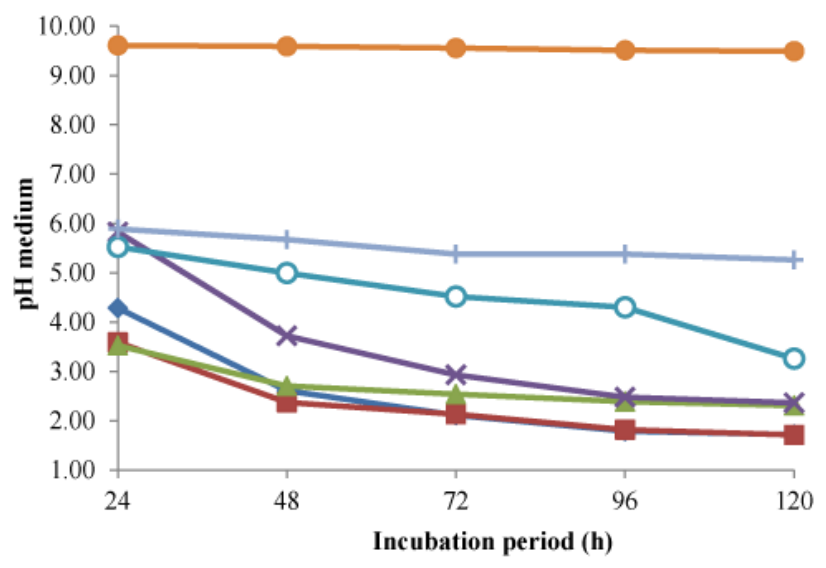

Figure 7: $\mathrm{pH}$ medium profile of Aspergillus brasiliensis using different nitrogen sources in SmF. Ammonium chloride (४); ammonium nitrate $(\cdot)$; ammonium sulphate $(\boldsymbol{\Delta})$; sodium nitrate $(\times)$; yeast extract $(0)$; urea $(\bullet)$; peptone $(+)$.

As mentioned earlier, biomass concentration is proportional to the xylanase activity in our study. The optimum growth temperature produces the highest biomass concentration of dry cell weight and spore count. In contrast, the growth temperature that produces the lowest xylanase activity is obtained from the lowest biomass concentration. Therefore, dry cell weight increased according to xylanase activity as shown in Figure 9(A). It is obvious from the graph that the optimum dry cell weight of $259.272 \mathrm{~g} / \mathrm{L}$ at $72 \mathrm{~h}$ was obtained when the culture medium was incubated at $30^{\circ} \mathrm{C}$, more precisely when the xylanase activity was optimum. Growth of $A$. brasiliensis at $28^{\circ} \mathrm{C}$, $32^{\circ} \mathrm{C}$ and $34^{\circ} \mathrm{C}$ produced dry cell weight of $97.7,109.2$ and $95.2 \mathrm{~g} / \mathrm{L}$, respectively. The lowest dry cell weight was $74.4 \mathrm{~g} / \mathrm{L}$ at $72 \mathrm{~h}$ when incubated at $36^{\circ} \mathrm{C}$. Figure 9 (B) illustrates the spore production of $A$. brasiliensis at various growth temperatures reported in the study. Growth of $A$. brasiliensis at $30^{\circ} \mathrm{C}$ produced more spores of $6.9 \times 10^{8}$ spores $/ \mathrm{mL}$ at $72 \mathrm{~h}$ as compared to $28^{\circ} \mathrm{C}, 32^{\circ} \mathrm{C}$ and $34^{\circ} \mathrm{C}$ which produced $5.0 \times 10^{8}, 4.5 \times 10^{8}$ and $3.7 \times 10^{8}$ spores $/ \mathrm{mL}$, respectively. However, the growth of $A$. brasiliensis at $36^{\circ} \mathrm{C}$ produced the least number of spores, $2.8 \times 10^{8}$ spores $/ \mathrm{mL}$ at $72 \mathrm{~h}$.

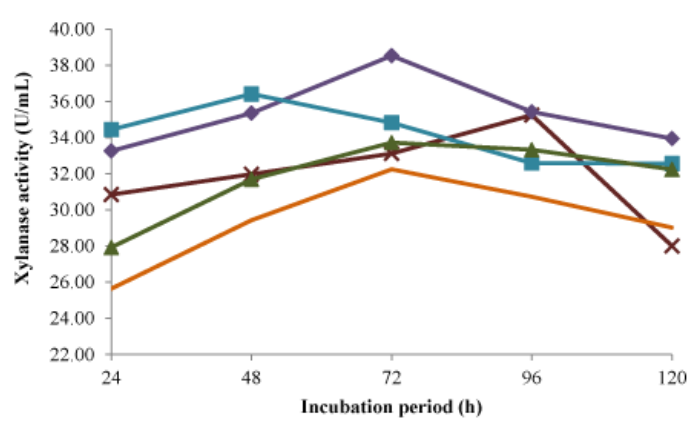

Figure 8: Effect of different growth temperatures on xylanase production by Aspergillus brasiliensis in $\mathrm{SmF} .28^{\circ} \mathrm{C}(\times) ; 30^{\circ} \mathrm{C}(\diamond)$; $32^{\circ} \mathrm{C}(\cdot) ; 34^{\circ} \mathrm{C}(\boldsymbol{\Delta}) ; 36^{\circ} \mathrm{C}(\bullet)$.
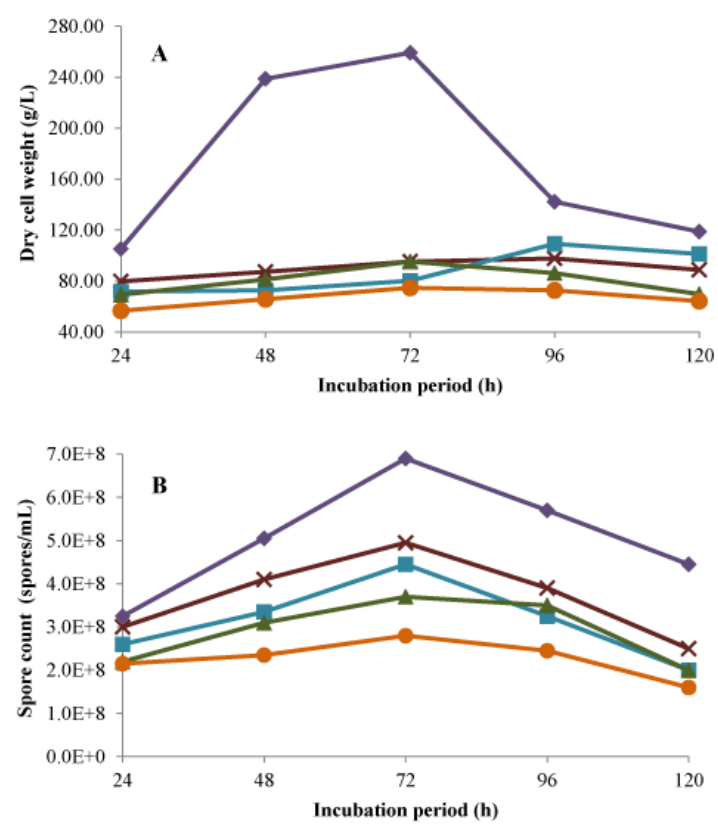

Figure 9: Effect of different growth temperatures on growth of Aspergillus brasiliensis. dry cell weight (A) and spore count (B) in SmF. $28^{\circ} \mathrm{C}(\times) ; 30^{\circ} \mathrm{C}(\bullet) ; 32^{\circ} \mathrm{C}(\bullet) ; 34^{\circ} \mathrm{C}(\boldsymbol{\Delta}) ; 36^{\circ} \mathrm{C}(\bullet)$.

The response of $A$. brasiliensis at different growth temperatures for the production of protein in culture medium is shown in Figure 10(A). A. brasiliensis was able to produce protein concentration of 0.016 $\mathrm{g} / \mathrm{mL}$ after incubated at $30^{\circ} \mathrm{C}$ for $120 \mathrm{~h}$. The same yield was reached when $A$. brasiliensis was incubated at $28^{\circ} \mathrm{C}$. The lowest protein concentration of $0.014 \mathrm{~g} / \mathrm{mL}$ at $72 \mathrm{~h}$ was obtained when incubated at $36^{\circ} \mathrm{C}$. Based on our results, the more the cells of $A$. brasiliensis 
Citation: Ho HL, Hood JS (2014) Optimisation of Medium Formulation and Growth Conditions for Xylanase Production by Aspergillus brasiliensis in Submerged Fermentation (SmF). J Biodivers Biopros Dev 1: 102. doi:10.4172/2376-0214.1000102

Page 9 of 13

produced, the lower the $\mathrm{pH}$ medium was achieved especially at $30^{\circ} \mathrm{C}$ Aspergillus spp is commonly used to produce citric acid in the industry. Thus, citric acid was produced in the medium as fermentation prolonged. As a result, it lower the $\mathrm{pH}$ of the medium when $A$. brasiliensis grown maximum at $30^{\circ} \mathrm{C}$ as shown in Figure 10(B). The $\mathrm{pH}$ that depicted in Figure 10(B) illustrates the impact of different temperatures of $28,30,32,34$ and $36^{\circ} \mathrm{C}$ on xylanase activity and biomass production by $A$. brasiliensis. At $30^{\circ} \mathrm{C}$, the $\mathrm{pH}$ reduced rapidly to 3.02 , where the xylanase activity was optimum at $72 \mathrm{~h}$, then, continued to decrease to $\mathrm{pH} 2.16$ at $120 \mathrm{~h}$. At $28^{\circ} \mathrm{C}, 32^{\circ} \mathrm{C}, 34^{\circ} \mathrm{C}$ and $36^{\circ} \mathrm{C}, \mathrm{pH}$ reduced gradually to $3.86,3.98,4.22$ and 4.30 at $120 \mathrm{~h}$, respectively. The results clearly exhibited that the yield of enzyme was significantly affected by growth temperature. Therefore, according to the results obtained at different growth temperatures, it can be concluded that the optimum temperature is $30^{\circ} \mathrm{C}$. This observation coincides with those of Ahmad et al. [9] whereby they studied the effect of growth temperatures on xylanase production by Aspergillus niger and they found out that the optimum xylanase activity of 64.47 $\mathrm{U} / \mathrm{mL}$ was obtained at $30^{\circ} \mathrm{C}$.
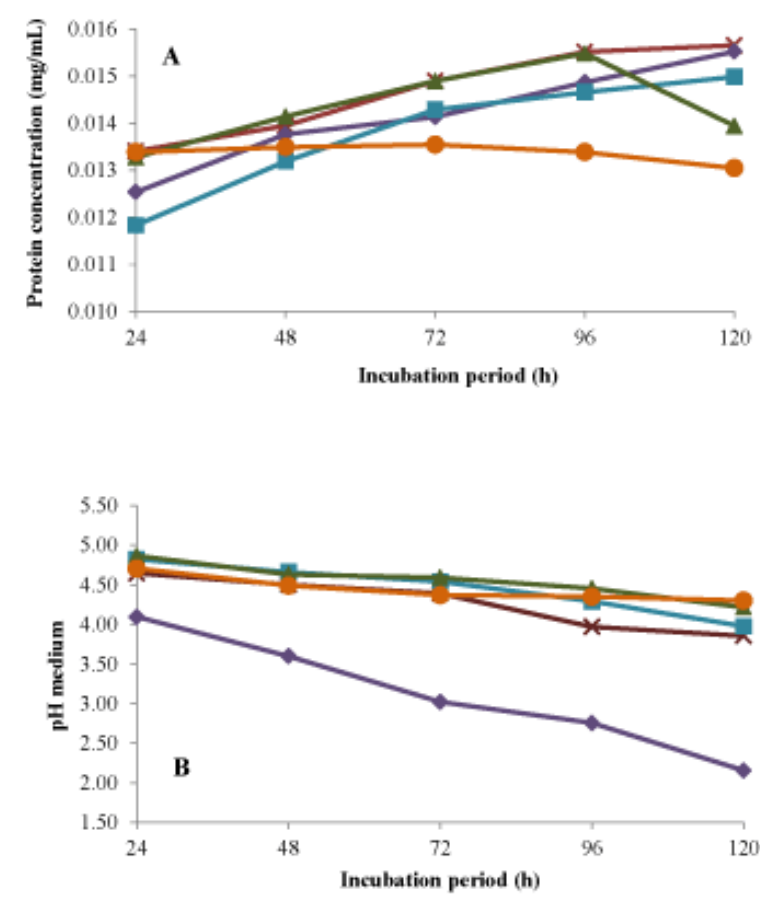

Figure 10: Effect of different growth temperatures on protein production by Aspergillus brasiliensis (A) and $\mathrm{pH}$ medium profile of Aspergillus brasiliensis (B) in SmF. $28^{\circ} \mathrm{C}(\times) ; 30^{\circ} \mathrm{C} \bullet$ ); $32^{\circ} \mathrm{C}(\cdot)$; $34^{\circ} \mathrm{C}(\boldsymbol{\Delta}) ; 36^{\circ} \mathrm{C}(\bullet)$.

\section{Effect of different $\mathrm{pH}$ medium on xylanase production}

The activity of xylanase depends strongly on the $\mathrm{pH}$ of the medium. The initial $\mathrm{pH}$ influences many enzymatic systems and their transport across the cell membrane [56]. Previous studies investigated various initial $\mathrm{pH}$ medium for xylanase production by different strains of fungi. Most fungi are reported to produce xylanase at initial $\mathrm{pH}$ lower than 7.0 [47-57]. Similarly, Grag [58] specified that most of the fungal produced the highest xylanase activity at the $\mathrm{pH}$ range of 6 to 6.5 . In contrast, some other reports shown that the initial $\mathrm{pH}$ range of 4 to 7 is the optimal $\mathrm{pH}$ for xylanase production by Aspergillus spp [59-62]. In our study, the effects of xylanase activity under different $\mathrm{pH}$ medium were recorded starting from 24 to $120 \mathrm{~h}$ as shown in Figure 11. Based on our results, when the culture medium with the initial $\mathrm{pH}$ adjusted to 6.5 , it produced the highest xylanase activity of $39.567 \mathrm{U} / \mathrm{mL}$ at $72 \mathrm{~h}$. From Figure 11, it can be seen that the xylanase activity of $\mathrm{pH} 6.5$ increased significantly from 24 to $72 \mathrm{~h}$ of fermentation and decreased slightly to $38.393 \mathrm{U} / \mathrm{mL}$ and $38.278 \mathrm{U} / \mathrm{mL}$ at 96 and $120 \mathrm{~h}$, respectively. On the other hand, substantial xylanase activity was observed starting from 24 to $72 \mathrm{~h}$ on medium with initial $\mathrm{pH}$ adjusted to 5.0. The xylanase activity reached a peak of $38.528 \mathrm{U} / \mathrm{mL}$ at $72 \mathrm{~h}$ which then declined to $33.946 \mathrm{U} / \mathrm{mL}$ at $120 \mathrm{~h}$. The decrease in xylanase activity might due to the action of proteolytic enzymes produced by the fungi. Similarly, when the $\mathrm{pH}$ medium for $A$. brasiliensis was maintained at $\mathrm{pH} 3.0,4.0,6.0$ and 7.0 through the fermentation process, moderate level of xylanase activity was detected. The cultures with initial $\mathrm{pH}$ medium of 3.0 and 4.0 reaching $31.199 \mathrm{U} / \mathrm{mL}$ and $32.636 \mathrm{U} / \mathrm{mL}$ both at $72 \mathrm{~h}$, respectively were also among the moderate level xylanase activities observed. According to Chidi et al. [63], moderate production of xylanase by Aspergillus terreus was observed, producing $28.6 \mathrm{U} / \mathrm{mL}$ when $\mathrm{pH}$ medium was adjusted to 6.0 .

In our study, lower xylanase activity of $27.912,24.329,7.339$ and $5.453 \mathrm{U} / \mathrm{mL}$ was observed when the initial $\mathrm{pH}$ medium was set to alkaline condition at 8.0, 9.0, 10.0 and 11.0, respectively. Likewise, Tallapragada and Venkatesh [35] also observed the maximum xylanase production of only $5.51 \mathrm{U} / \mathrm{mL}$ when $\mathrm{pH}$ medium was initially adjusted to 8.0. This indicates that the fungi was not able to grow at high alkaline condition and hence, xylanase synthesis was inactivated. In our study, the xylanase activity at various $\mathrm{pH}$ increased with the fermentation time up to a certain period and started showing a slow decline after $72 \mathrm{~h}$. This might be due to the exhaustion of nutrients occurred in fungi during fermentation. However, almost no xylanase activity was detected when the culture medium was adjusted to the initial $\mathrm{pH} 10$ and 11 . This might due to the inability of $A$. brasiliensis to grow at the alkaline $\mathrm{pH}$ condition. This is further confirmed by the studies observed on xylanase production by different fungi such as Cochliobolus sativus [28] and Fusarium solani [54]. Hence, less xylanase activity was observed in the alkaline $\mathrm{pH}$ medium. Our findings agree well with the earlier studies that proved the xylanase production by bacteria and fungi was remarkably dependent on the $\mathrm{pH}$ medium [64]. In conclusion, $\mathrm{pH} 6.5$ is the optimum initial $\mathrm{pH}$ for xylanase activity by $A$. brasiliensis.

Different $\mathrm{pH}$ values showed a significant increase in xylanase activity as well as its biomass concentration. Even though the highest dry cell weight of $259.2 \mathrm{~g} / \mathrm{L}$ at $72 \mathrm{~h}$ was observed when the initial $\mathrm{pH}$ medium was adjusted to 5.0, however the xylanase activity was only $38.528 \mathrm{U} / \mathrm{mL}$ (Figure 12A). In contrast, when the $\mathrm{pH}$ medium was adjusted to 6.5 , the highest xylanase activity of $39.567 \mathrm{U} / \mathrm{mL}$ at $72 \mathrm{~h}$ was obtained even with $190.5 \mathrm{~g} / \mathrm{L}$ of dry cell weight. Therefore, at $\mathrm{pH}$ medium near to neutral, our study showed that the production of xylanase was the highest even with slight lower amount of dry cell weight of $A$. brasiliensis. This indicates that the xylanase synthesis was not only influenced by biomass concentration but the initial $\mathrm{pH}$ medium as well. The number of spores in culture medium at $\mathrm{pH} 6.5$ as shown in Figure 12(B) was found to be the highest, producing $7.5 \times 10^{8}$ spores $/ \mathrm{mL}$ at $72 \mathrm{~h}$. The spore count decreased to $4.2 \times 10^{8}$ spores $/ \mathrm{mL}$ at 120 h. Meanwhile, the impact of $\mathrm{pH}$ medium on biomass 
Citation: Ho HL, Hood JS (2014) Optimisation of Medium Formulation and Growth Conditions for Xylanase Production by Aspergillus brasiliensis in Submerged Fermentation (SmF). J Biodivers Biopros Dev 1: 102. doi:10.4172/2376-0214.1000102

Page 10 of 13

concentration at $\mathrm{pH} 5.0$ was also high. The highest spore count of $6.9 \times 10^{8}$ spores $/ \mathrm{mL}$ was obtained at $72 \mathrm{~h}$ which decreased to $4.5 \times 10^{8}$ spores $/ \mathrm{mL}$ at $120 \mathrm{~h}$. On the other hand, the lowest dry cell weight of $75.2 \mathrm{~g} / \mathrm{L}$ was observed at culture medium adjusted to $\mathrm{pH} 11.0$ (Figure 12A). The lowest spore count of $2.0 \times 10^{5}$ spores $/ \mathrm{mL}$ was also observed when culture medium was adjusted to $\mathrm{pH} 11.0$. This might be due to the fact that alkaline $\mathrm{pH}$ has inhibitory effect on the growth of $A$. brasiliensis and xylanase production.

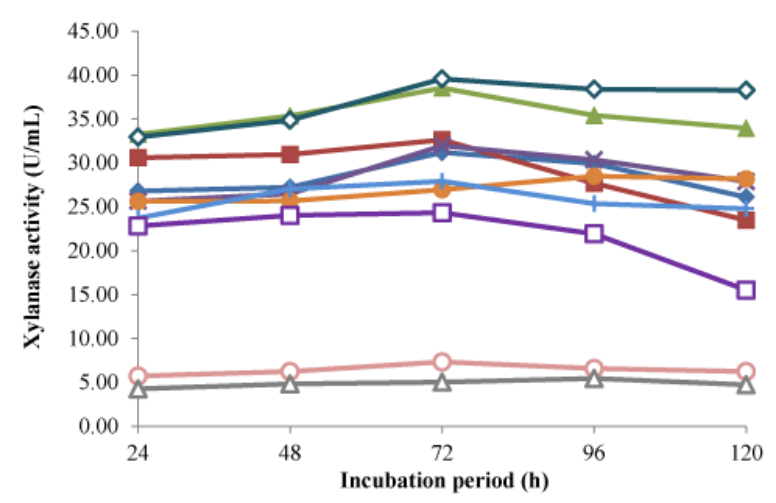

Figure11: Effect of different $\mathrm{pH}$ medium on xylanase production by Aspergillus brasiliensis in SmF. pH 3 (४); pH 4 (•); pH 5 (এ); pH 6 $(\times)$; pH $6.5(\diamond)$; pH 7 (๑); pH 8 (+); pH 9 (๑); pH $10(\circ)$; pH $11(\Delta)$.
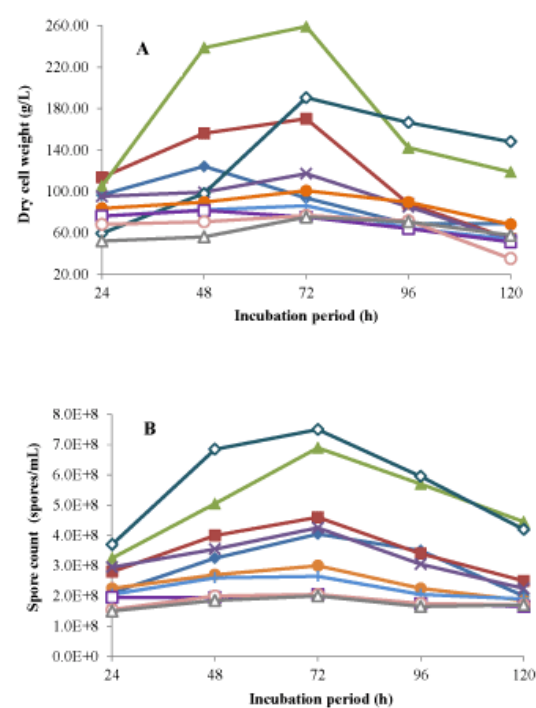

Figure 12: Effect of different $\mathrm{pH}$ medium on growth of Aspergillus brasiliensis. dry cell weight (A) and spore count (B) in SmF. pH 3 $(\bullet)$; pH $4(\bullet)$; pH $5(\boldsymbol{\Delta})$; pH $6(\times)$; pH $6.5(\diamond)$; pH $7(\bullet)$; pH $8(+)$; pH 9 (); pH 10(०); pH $11(\Delta)$.

The optimum protein concentration of $0.028 \mathrm{~g} / \mathrm{mL}$ at $96 \mathrm{~h}$ was produced by the initial $\mathrm{pH}$ medium adjusted to $\mathrm{pH} 6.5$ as shown in (Figure 13). The protein concentration obtained at this $\mathrm{pH}$ medium is extremely high as compared to the other remaining $\mathrm{pH}$ medium. $\mathrm{pH}$ medium at 5.0 obtained its highest protein concentration of 0.016 $\mathrm{g} / \mathrm{mL}$ at $120 \mathrm{~h}$ followed by $\mathrm{pH} 3.0$ and 4.0 which produced $0.015 \mathrm{~g} / \mathrm{mL}$ at $120 \mathrm{~h}$. Similarly, $\mathrm{pH}$ medium at 6.0, 7.0, 8.0 and 9.0 produced lower protein concentrations of $0.014,0.014,0.013$ and $0.012 \mathrm{~g} / \mathrm{mL}$ at $120 \mathrm{~h}$, respectively. Low protein concentrations of $0.012 \mathrm{~g} / \mathrm{mL}$ were also observed in both $\mathrm{pH}$ medium 10 and 11 at $72 \mathrm{~h}$. However, for culture medium at $\mathrm{pH} 6.5$, it gradually decreased to 4.52 at $72 \mathrm{~h}$ when the optimum xylanase activity was observed. These observations indicated that xylanase activity in acid condition was higher than the alkaline conditions. In addition, Jin et al. [65] investigated the optimised culture conditions for Aspergillus flavus Mtcc 9390. They observed $80 \%$ of xylanase activity occurred from $\mathrm{pH} 3.0$ to 9.0 and even higher at $90 \%$ of xylanase activity was attained when the medium cultured from $\mathrm{pH} 3.0$ to 7.0. Hence, it can be concluded that in our study, $\mathrm{pH}$ 6.5 was found to be the optimum $\mathrm{pH}$ for xylanase activity by $A$. brasiliensis. Our results coincide with those of Knob and Carmona [66], whereby the optimum xylanase production by Penicillium sclerotiorum was obtained in medium adjusted to $\mathrm{pH} 6.5$ and cultured at $30^{\circ} \mathrm{C}$.

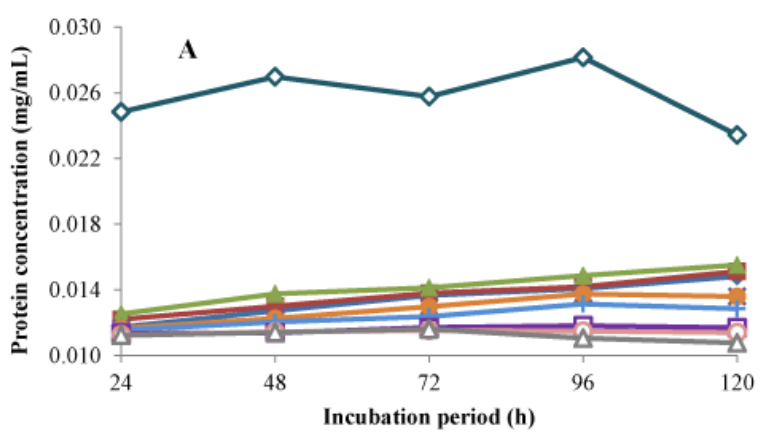

Figure 13: Effect of different $\mathrm{pH}$ medium on protein production by Aspergillus brasiliensis in SmF. $\mathrm{pH} 3(\diamond)$; $\mathrm{pH} 4(\bullet) ; \mathrm{pH} 5(\boldsymbol{\Lambda}) ; \mathrm{pH} 6$ $(\times)$; pH $6.5(\diamond)$; pH 7 (•); pH 8 (+); pH 9(); pH 10 (०); pH $11(\Delta)$.

\section{Optimisation of medium formulation and growth conditions for production of xylanase by Aspergillus brasiliensis in submerged fermentation $(\mathrm{SmF})$}

Xylanase production can be improved by optimising the medium formulation and growth conditions of $A$. brasiliensis. In our study, $A$. brasiliensis synthesized the highest xylanase production at $72 \mathrm{~h}$ of fermentation. The xylanase production increased gradually with the constant progress of fermentation time, but after $96 \mathrm{~h}$, a decrease in xylanase activity was observed. This might due to the exhaustion of nutrients from the medium that affected the growth of fungi and hence, decreasing the enzyme activity. Furthermore, towards the end of fermentation period, the formation of thick suspension medium with biomass was observed, leading to the improper mixing of nutrients in the shake flask. As a result, lesser oxygen was available, and thus, creating the poor gas transfer for $A$. brasiliensis. This is probably another major reason for the decrease of xylanase activity in the culture medium.

In the present study, xylanase yield increased gradually with time where $A$. brasiliensis produced the maximum xylanase at $72 \mathrm{~h}$ of fermentation. Thereafter, the depletion of nutrients from the culture medium caused the negative impact on fungal growth or might due to 
proteolysis [67], thus resulting in reduced xylanase synthesis. Likewise, Cai et al. [68] and Senthilkumar et al. [69] also observed the maximum xylanase activity at $72 \mathrm{~h}$ of fermentation. Several other studies were also found that the optimum incubation period for xylanase activity was at $72 \mathrm{~h}$ by a wide variety of microorganisms such as Arthrobacter spp. [70], Aspergillus spp. [71] and Aspergillus niger [72]. According to Seyis and Aksoz [5], the production costs are directly proportional to the production time. In order to minimize the production costs, xylanase should be produced in the shortest possible time. Thus, it was interesting to report that $A$. brasiliensis in our study was able to produce the maximum production of xylanase at shorter fermentation period to reduce the cost of production when scaling-up is performed.

In contrast, there are many studies show the optimum xylanase activity observed at the longer time of fermentation. Palma et al. [73] and Kohli et al. [74] reported the maximum xylanase production after $96 \mathrm{~h}$. The optimum activity of xylanase was also observed at $120 \mathrm{~h}$ by Kansoh and Gammel [75], Park et al. [76] and Agnes et al. [77], respectively. The differences of these results are probably due to the variation of fermentation parameters including medium formulation, $\mathrm{pH}$ medium, agitation speed as well as inoculation size. Apparently, in the industrial point of view, it is very crucial to have the maximum enzyme production in the shortest production time possible in order to reduce the cost of production as well as to lessen the risk of contamination especially in batch culture. Thus, the optimisation of medium and growth conditions is the fundamental study of our research to fabricate mass production of xylanase for purification and recovery in the future.

The growth of $A$. brasiliensis was highly affected by their xylanase activity. However in some culture medium, the growth stimulates a higher yield of biomass concentration even though the xylanase activity is low. Tippani et al. [78] reported that the production of the enzyme was not always directly proportional to the biomass concentration. This indicates that a specific medium composition and culture condition which produces the optimum xylanase activity does not necessarily produce the higher biomass concentration. Different species of fungi require specific medium formulation as well as culture condition. In this study, $A$. brasiliensis was found to grow optimum at $30^{\circ} \mathrm{C}$ using the initial $\mathrm{pH}$ medium 6.5 when sucrose and yeast extract were used as the optimized carbon and nitrogen sources.

\section{Conclusion}

The present study provides the direct comparison of different fermentation parameters to produce the optimum xylanase activity by A. brasiliensis using $\mathrm{SmF}$. SmF is preferred due to the efficient aeration, better distribution of nutrients, sufficient gas exchanges and supply of oxygen during fermentation process. Xylanases produced from $A$. brasiliensis was found to be satisfactory in terms of activity and its biomass concentration. Various carbon sources were investigated and sucrose was found to be the optimum carbon source in medium formulation for xylanase activity by $A$. brasiliensis. Besides sucrose, glucose and maltose were also showed a positive correlation with xylanase production as well. However, ethanol had a negative effect on xylanase activity most likely because it did not enhance the growth of $A$. brasiliensis in the medium. Besides that, the supplementation of nitrogen sources in the culture medium was also influenced the growth of $A$. brasiliensis. Thus, much higher xylanase activity was achieved when yeast extract was supplied in the medium. Nevertheless, medium with peptone also provided appreciable xylanase activity. Inorganic nitrogen sources such as $\mathrm{NaNO}_{3}$ and
$\mathrm{NH}_{4} \mathrm{NO}_{3}$ produced high yield of xylanase activity as well. In conclusion, the maximum xylanase activity was preferable in medium containing yeast extract as compared to the other nitrogen sources in this study.

The control of fermentation parameters such as growth temperature and $\mathrm{pH}$ medium affects the xylanase activity significantly at various levels. Based on our result, from all the growth temperatures used for the optimisation study of culture conditions, $A$. brasiliensis produced the optimum xylanase activity at $30^{\circ} \mathrm{C}$. However, an increase in growth temperature led to the decrease in the xylanase activity. Besides that, xylanase activity was also decreased in the higher $\mathrm{pH}$ medium compared to the lower $\mathrm{pH}$ medium. In other words, xylanase activity was observed from the $\mathrm{pH}$ range of 3.0 to 6.5. More precisely, the maximum xylanase activity by $A$. brasiliensis was observed when the $\mathrm{pH}$ medium was initially adjusted to 6.5. Therefore, in our study, the optimum fermentation period occurred at $72 \mathrm{~h}$, where the highest xylanase activity by $A$. brasiliensis was achieved at $30^{\circ} \mathrm{C}$ with the initial $\mathrm{pH}$ medium adjusted to 6.5. In conclusion, the maximum xylanase synthesis by $A$. brasiliensis was achieved at $30^{\circ} \mathrm{C}$ with the initial $\mathrm{pH}$ medium 6.5 using sucrose and yeast extract as the optimised carbon and nitrogen sources in $\mathrm{SmF}$.

\section{References}

1. Techapun C, Poosaran N, Watanabe M, Sasaki K (2003) Thermostable and alkaline tolerant microbial cellulase-free xylanases produced from agricultural wastes and the properties required for use in pulp bleaching bioprocesses: A review, Process Biochem 38: 1327-1340.

2. Simoes MLG, Tauk-Tornisielo SM, Tapia DMP (2009) Screening of culture condition for xylanase production by filamentous fungi. Afr J Biotechnol 8: 6317-6326.

3. Haq I, Tasneem M, Raana K, Khan A, Mukhtar H, Javed HM (2004) Optimization of cultural conditions for the production of xylanase by chemically mutated strain of A. niger GCBCX-20. Int J Agric Biotechnol 6: 1115-1118.

4. Azin M, Moravej R, Zareh D (2007) Production of xylanase by Trichoderma longibrachiatum on a mixture of wheat bran and wheat straw: Optimization of culture condition by Taguchi method. Enzyme Microbiol Technol 40: 801-805.

5. Seyis I, Aksoz N (2005) Effect of carbon and nitrogen sources on xylanase production by Trichoderma harzianum 1073 D3. Int Biodeterioration Biodegradation 55: 115-119.

6. Haq I, Khan A, Butt WA, Ali S, Qadeer MA (2002) Effect of carbon and nitrogen sources on xylanase production by mutant strain of Aspergillus niger GCBMX-45. J Biological Sci 2: 143-144.

7. Ahmad Z, Butt MS, Anjum FM, Awan MS, Rathore HA, et al. (2012) Effect of corn cobs concentration on xylanase biosynthesis by Aspergillus niger. Afr J Biotechnol 11: 1674-1682.

8. Cai Q, Yue T, Cheng J, Ma Q (2003) The screening of culture condition and properties of xylanase by white rot fungus Pleorotus ostreatus. Proc Biochem 25: 2-6.

9. Ahmad Z (2009) Production and characterization of xylanase for utilization in baking industry. University of Agriculture, Faisalabad.

10. Thakur VV, Jain RK, Mathur RM (2012) Studies on xylanase and laccase enzymatic prebleaching to reduce chlorine-based chemicals during $\mathrm{CEH}$ and ECF bleaching. BioResources 7: 2220-2235.

11. Rashid AN (1999) Characterization of xylanase produced by Bacillus pumilus strain PJ19. Journal of Microbial Biotechnology 9 : 157-162.

12. Bailey MJ, Biely P, Poutanen K (1992) Interlaboratory testing of methods for assay of xylanase activity. J Biotechnol 23: 257-270.

13. LOWRY OH, ROSEBROUGH NJ, FARR AL, RANDALL RJ (1951) Protein measurement with the Folin phenol reagent. J Biol Chem 193: $265-275$. 
14. Pham PL, Taillandier P, Delmas M, Strehaiano P (1998) Production of xylanases by Bacillus polymyxa using lignocellulosic wastes. Industrial Crops and Products 7: 195-203.

15. Kubicek CP, Röhr M. (1989) Citric acid fermentation. Crit Rev Biotechnol 4: 331-373.

16. Sati SC1, Bisht S (2006) Utilization of various carbon sources for the growth of waterborne conidial fungi. Mycologia 98: 678-681.

17. Rifaat HM, Nagieb ZA, Ahmed YM (2005) Production of xylanase by Streptomyces species and the bleaching effect on rice straw pulp. Appl Eco Environ Res 4: 151-160.

18. Asha Augustine, Imelda Joseph, Raj RR (2006) Biomass estimation of Aspergillus niger S, a mangrove fungal isolate and A. oryzae NCIM 1212 in solid-state fermentation. J. of the Marine Biological Association of India 48: 139-146.

19. Altaf SA, Umar DM, Muhammad MS (2010) Production of xylanase enzyme by Pleurotus eryngii and Flamulina velutipes grown on different carbon sources under submerged fermentation. World Appl Sci J 8 47-49.

20. D'Souza-Ticlo D1, Garg S, Raghukumar C (2009) Effects and interactions of medium components on laccase from a marine-derived fungus ussing response surface methodology. Mar Drugs 7: 672-688.

21. Carlsen M, Nielsen J, Villadsen J (1996) Growth and amylase production by Aspergillus oryzae during continuous cultivations. J Biotechnol 45: 81-93.

22. Oshoma CE, Imarhiagbe EE, Ikenebomeh MJ, Eigbaredon HE (2010) Nitrogen supplements effect on amylase production by Aspergillus niger using cassava whey medium. Afr J Biotechnol 9: 682-686.

23. Bhushan B, Pal A, Jain V (2012) Isolation, screening and optimized production of extracellular xylanase under submerged condition from Aspergillus flavus Mtcc 9390. Enzyme Engg 1: 103.

24. Kumar D, Verma R, Sharma P, Rana A, Sharma R, et al. (2012) Production and partial purification of xylanase from a new thermophilic isolate. Biological Forum-An Int J 2: 83-87.

25. Aqeel BM, Umar DM (2010) Effect of alternative carbon and nitrogen sources on production of alpha-amylase by Bacillus megaterium. World Appl Sci J 8: 85-90.

26. Pal P, Kaushik P (2012) Effect of carbon and nitrogen sources on the growth of Rhizoctonia solani isolated from Rhynchostylis retusa. Int J Life Sci 1: 16-18.

27. Li X, Sun B, Zhao J, Lv Y, Li HSE, Zhu Y (2011) Production and improved bleaching abilities of a thermostable xylanase from a newly isolated Streptomyces chartreusis strain. Afr J Biotechnol 10: 14132-14142.

28. Bakri Y1, Al-Jazairi M, Al-Kayat G (2008) Xylanase production by a newly isolated Aspergillus niger SS7 in submerged culture. Pol J Microbiol 57: 249-251.

29. Goyal M1, Kalra KL, Sareen VK, Soni G (2008) Xylanase production with xylan rich lignocellulosic wastes by a local soil isolate of Trichoderma viride. Braz J Microbiol 39: 535-541.

30. Abdel-Naby, Mohamed A, Kwon DY (1992) Production of xylanase and xylosidase by Aspergillus niger NRC 107. Korean J Appl Microbial Biotechnol 20: 543-550.

31. Kuhad RC, Chopra P, Battan B, Kapoor M, Kuhad S (2006) Production, partial purification and characterization of a thermo-alkali stable xylanase from Bacillus sp. RPP-1. Ind J Microbiol 46: 13-23.

32. Pal A1, Ramana KV, Bawa AS (2010) Simplification and optimization of deMan Rogosa Sharpe (MRS) medium for enhanced production of bacteriocin by Weissella paramesenteroides DFR-8. J Food Sci Technol 47: 258-265.

33. Sa-Pereira P, Mesquita A, Duarte JC, Barros MRA, Costa-Ferreira M (2002) Rapid production of thermostable cellulase free xylanase by a strain of Bacillus subtilis and its properties. Enzyme and Microbial Technol 30: 924-933.

34. Haltrich D, Nidetzky B, Kulke KD, Steiner W, Zupanie S (1997) Production of fungal xylanases. Bioresource Technol 58: 137-161.
35. Tallapragada P, Venkatesh K (2011) Isolation, identification and optimization of xylanase enzyme produced by Aspergillus niger under submerged fermentation. J Microbiol Biotechnol Res 1: 137-147.

36. Bajaj B, Razdan K, Sharma A (2010) Thermoactive alkali-stable xylanase production from a newly isolated Streptomyces sp. SU9. Ind J Chem Technol 17: 375-380.

37. Singh S1, Tyagi CH, Dutt D, Upadhyaya JS (2009) Production of high level of cellulase-poor xylanases by wild strains of white-rot fungus Coprinellus disseminatus in solid-state fermentation. N Biotechnol 26: 165-170.

38. Arrizon J, Gschaedler A (2002) Increasing fermentation efficiency at high sugar concentrations by supplementing an additional source of nitrogen during the exponential phase of the tequila fermentation process. Can J Microbiol 48: 965-970.

39. Haapala R, Linko S, Parkinen E, Suominen P (1994) Production of endo-1,4-B-glucanase and xylanase by Trichoderma reesei immobilized on polyurethane foam. Biotechnological Techniques 8: 401-406.

40. Ikenebomeh MJ, Chikwendu AE (1997) Aspergillus niger biomass production in cassava whey medium. Nig J Microbiol 11: 52-63.

41. Atalla MM, Hamed ER, El-Shami AR (2008) Optimization of a culture medium for increased mevinolin production by Aspergillus terreus strain. Mal J Microbiol 4: 6-10.

42. Stanbury PF, Whitaker A, Hall SJ (1994) Principles of fermentation technology. Butterworth-Heinemann. pp - 350.

43. Reid ID (1989) Solid-state fermentation for biological delignification. Enzyme and Microbial Technol 11: 786-803.

44. Suresh PV, Chandrasekaran M (1999) Impact of process parameters on chitinase production by an alkalophilic marine Beauveria bassiana in solid state fermentation. Proc Biochem 34: 257-267.

45. Adinarayana K, Prabhakar T, Srinivasulu V, Anitha RM, Jhansi LP, et al. (2003) Optimization of process parameters for cephalosporin C production under solid state fermentation from Acremonium chrysogenum. Proc Biochem 39: 171-177.

46. Rahman AK, Sugitani N, Hatsu M, Takamizawa K (2003) A role of xylanase, alpha-arabinofuranosidase and xylosidase in xylan degradation. Can J Microbiol 49: 58-64.

47. Subramaniyan S1, Prema P (2002) Biotechnology of microbial xylanases: enzymology, molecular biology, and application. Crit Rev Biotechnol 22: 33-64.

48. Murugan S1, Arnold D, Pongiya UD, Narayanan PM (2011) Production of Xylanase from Arthrobacter sp. MTCC 6915 Using Saw Dust As Substrate under Solid State Fermentation. Enzyme Res 2011: 696942.

49. Yaun Q, Rungyu M (1999) Study on temperature oscillation in production of xylanase by Aspergillus niger. Beijing Hugagong Daxue Xuebao 26: 13-16 (in Chinese).

50. Dueñas R1, Tengerdy RP, Gutierrez-Correa M (1995) Cellulase production by mixed fungi in solid-substrate fermentation of bagasse. World J Microbiol Biotechnol 11: 333-337.

51. Ali S, Haq I, Qadeer MA, Iqbal J (2002) Production of citric acid by Aspergillus niger using cane molasses in a stirred fermentor. Electron $\mathrm{J}$ Biotechnol 5: 258-271.

52. Chen H1, Zhu J, Liang G, Yan Z, Zhang S (1999) [Screening of acidic xylanase producing strain and studies on its enzyme production conditions]. Wei Sheng Wu Xue Bao 39: 350-354.

53. Bailey MJ, Biely P, Poutanen K (1989) Production of xylanolytic enzymes by strains of Aspergillus. Appl Microbiol Biotechnol 30: 5-10.

54. Gupta VK, Gaur R, Yadava SK, Darmwal NS (2009) Optimization of xylanase production from free and immobilized cells of Fusarium solani F7. BioResourses 4: 932-945.

55. Prasertsan P, Kittikul AH, Kunghae A, Maneesri J, Oi S (1997) Optimization for xylanase and cellulose production from Aspergillus niger ATTC 6275 in palm oil mill wastes and its application. World J Microbiol Biotechnol 13: 555-559. 
Citation: Ho HL, Hood JS (2014) Optimisation of Medium Formulation and Growth Conditions for Xylanase Production by Aspergillus brasiliensis in Submerged Fermentation (SmF). J Biodivers Biopros Dev 1: 102. doi:10.4172/2376-0214.1000102

Page 13 of 13

56. Shah AR, Madamwar D (2005) Xylanase production by newly isolated Aspergillus foetidus strain and its characterization. Proc Biochem 40: 1763-1771.

57. Poorna CA, Prema P (2007) Production of cellulose-free endoxylanase from novel alkalophilic thermotolerent Bacillus pumilus by solid-state fermentation and its application in wastepaper recycling. Bioresources Technol 98: 485-490.

58. Grag AP (1996) Biobleaching effect of Streptomyces thermoviolaceous xylanase preparation on birchwood kraft pulp. Enzyme Microbial Technol 18: 263-267.

59. Fernandez-Espinar MT, Ramon D, Pinaga F, Valles S (1992) Xylanase production by Aspergillus nidulans. FEMS Microbiol 91: 91-96.

60. Ghosh M, Das A, Mishra AK, Nanda G (1993) Aspergillus sydowii MG 49 a strong producer of thermostable xylanolytic enzymes. Enzyme Microbial Technol 15: 703-709.

61. Raj KC, Chandra TS (1995) Production of cellulase-free xylanase from alkali tolerant Aspergillus fischeri. Biotechnol Lett 17: 309-314.

62. Carmona EC, Pizzarani-Kleiner AA, Monteiro RTR, Jorge JA (1997) Xylanase production by Aspergillus versicolor. J Basic Microbiol 37: 387-394.

63. Chidi SB, Godana B, Ncube I, van Rensburg EJ, Cronshaw A (2008) Production, purification and characterization of cellulase-free xylanase from Aspergillus terreus UL 4209. Afr J Biotechnol 7: 3939-3948.

64. Wong KK, Tan LU, Saddler JN (1988) Multiplicity of beta-1,4-xylanase in microorganisms: functions and applications. Microbiol Rev 52: 305-317.

65. Jin N, Ma S, Liu Y, Yi X, He R, et al. (2012) Thermophilic xylanase production by Aspergillus niger in solid state fermentation using wheat straw and corn cob. Afr J Microbiol 6: 2387-2394.

66. Knob A, Carmona EC (2008) Xylanase production by Penicillium sclerotiorum and its characterization. World Appl Sci J 4: 277-283.

67. Flores ME, Perez R, Huitron C (1997) B-Xylosidase and xylanase characterization and production by Streptomyces sp. CH-M-1035. Lett Appl Microbiol 24: 410-416.

68. Cai JM, Ke W, Zhow Y, Jie Z, Bang J, et al. (1997) Production of xylanase by Penicillium sp. P1 using solid state fermentation. ShipinYu Fajio Gongye 23: 30-33 (in Chinese).
69. Senthilkumar SR, Ashokkumar B, Chandra K Raj, Gunasekaran P (2005) Optimization of medium composition for alkali-stable xylanase production by Aspergillus fischeri Fxn 1 in solid-state fermentation using central composite rotary design. Bioresources Technol 96: 1380-1386.

70. Khandeparkar R1, Bhosle NB (2007) Application of thermoalkalophilic xylanase from Arthrobacter sp. MTCC 5214 in biobleaching of kraft pulp. Bioresour Technol 98: 897-903.

71. Camacho NA1, Aguilar O G (2003) Production, purification, and characterization of a low-molecular-mass xylanase from Aspergillus sp. and its application in baking. Appl Biochem Biotechnol 104: 159-172.

72. Widjaja A, Lestari E, Tanjung A, Widiawan, Alfian, Ogino H (2009) Optimized production of xylanase from fungal strains and its purification strategies. J Appl Sci Environ Sanitation 4: 219-232.

73. Palma MB, Milagres AMF, Prata AMR, Manicilha DIM (1996) Influence of aeration and agitation on xylanase production. Bra J Biochem 31: 141-145.

74. Kohli U1, Nigam P, Singh D, Chaudhary K (2001) Thermostable, alkalophilic and cellulase free xylanase production by Thermoactinomyces thalophilus subgroup C. Enzyme Microb Technol 28: 606-610.

75. Kansoh AL1, M-Ali A, A-el-Gammal A (2001) Xylanolytic activities of Streptomyces sp. 1--taxonomy, production, partial purification and utilization of agricultural wastes. Acta Microbiol Immunol Hung 48: 39-52.

76. Park YS, Kang SW, Lee JS, Hong SI, Kim SW (2002) Xylanase production in solid state fermentation by Aspergillus niger mutant using statistical experimental designs. Appl Microbiol Biotechnol 58: 761-766.

77. Agnes E, Asagbra I, Sanni, Olusola B (2005) Solid-state fermentation production of tetracycline by Streptomyces strains using some agricultural wastes as substrate. World J Microbiol Biotechnol 21: 107-114.

78. Tippani R, Sivadevuni G (2012) Nutritional factors effecting the production of L-asparaginase by the Fusarium sp. Afr J Biotechnol 11: 3692-3696. 